This item was submitted to Loughborough's Research Repository by the author.

Items in Figshare are protected by copyright, with all rights reserved, unless otherwise indicated.

Conversion to protestant Christianity in China and the 'supply-side model': explaining changes in the Chinese religious field

PLEASE CITE THE PUBLISHED VERSION

http://dx.doi.org/10.1080/0048721X.2011.624694

PUBLISHER

(c) Taylor \& Francis

VERSION

AM (Accepted Manuscript)

LICENCE

CC BY-NC-ND 4.0

REPOSITORY RECORD

Klein, Thoralf. 2019. "Conversion to Protestant Christianity in China and the 'supply-side Model': Explaining Changes in the Chinese Religious Field". figshare. https://hdl.handle.net/2134/15040. 
This item was submitted to Loughborough's Institutional Repository (https://dspace.lboro.ac.uk/) by the author and is made available under the following Creative Commons Licence conditions.

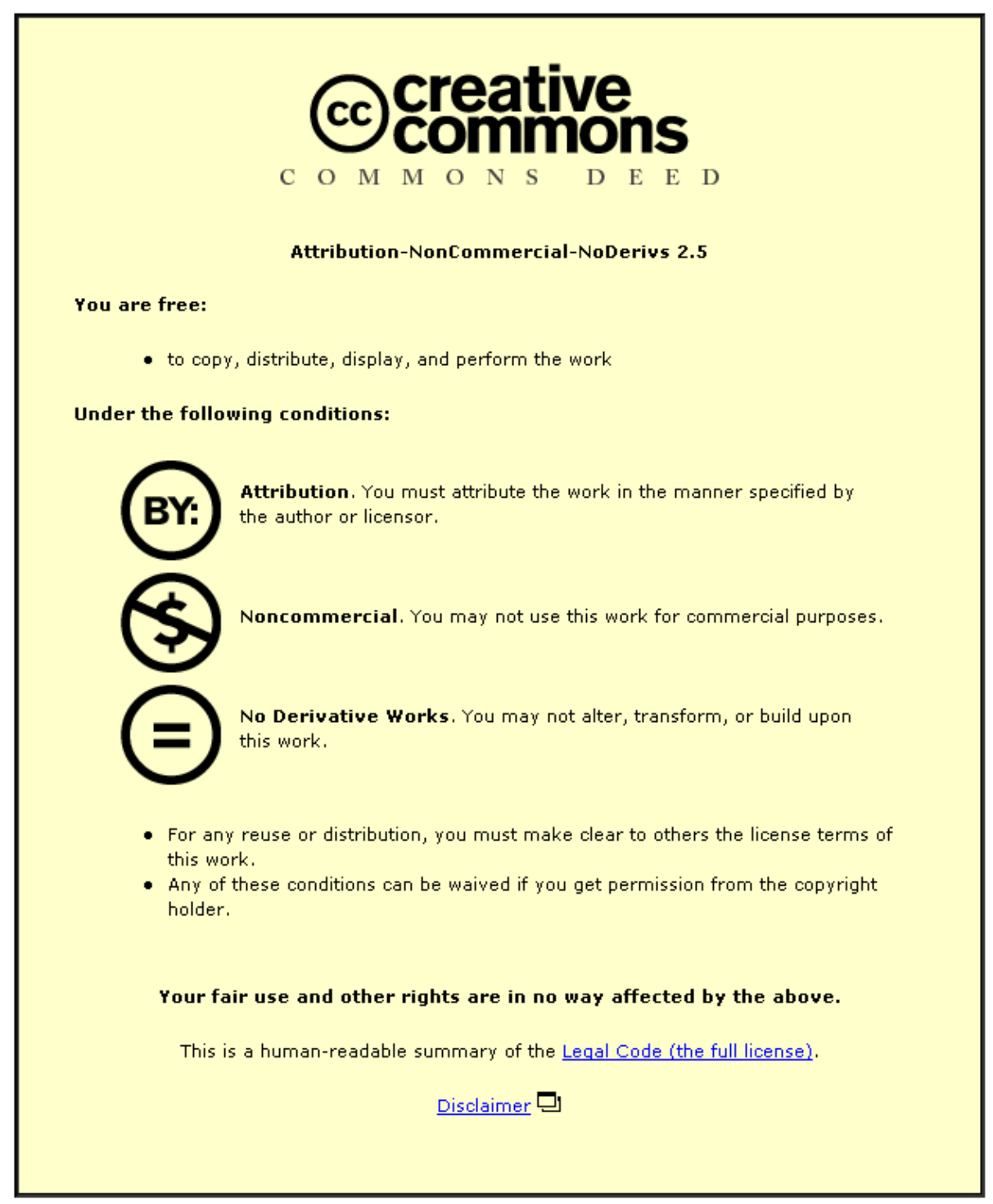

For the full text of this licence, please go to: http://creativecommons.org/licenses/by-nc-nd/2.5/ 


\title{
Conversion to Protestant Christianity in China and the 'Supply-side Model': Explaining Changes in the Chinese Religious Field
}

\author{
Thoralf Klein
}

\begin{abstract}
In this article, I put the 'supply-side model' advocated by religious economists to an empirical test. The 'supply-side' model in some measure already constitutes a move 'beyond the market', as it seeks to expand and enlarge the economic interpretation of religion by linking it to a concept of networks and social tensions and integrating the concept of religious and cultural capital. In applying the model to the (dynamics of the) historical growth of Protestantism in nineteenth and early twentieth-century China, I examine three distinct aspects of the conversion process: the supply-side (missionaries), the demand niches (Chinese converts) and the question of 'strict' churches. Arguing that the religious background of Protestant converts - their rootedness in Chinese popular religion - determined this process through, I seek to develop an understanding of religious competition, supply and demand that takes cultural interpretive frameworks into account.
\end{abstract}

Keywords: theory of religion, religious economy, China, Christianity, Protestantism

One of the central aspects of the religious economy approach is its explanation of religious change. Such change is understood as a shift in the ensemble of religious activities in a society, referred to within this theoretical framework as a religious economy. In their co-authored book Acts of Faith (2000: 194), Rodney Stark and Roger Finke - two of the main proponents of economic approach to religion - have made a sweeping statement, arguing that "when exclusive firms appear in religious economies previously dominated by non-exclusive groups, the exclusive firm(s) become dominant." Stark and Finke cite the rise of Judaism, Christianity, and Islam as historical evidence of how exclusive competitors came to dominate "a relatively unregulated market" because each was "the better bargain, despite requiring higher costs" (ibid.). These examples, which can be given with the benefit of hindsight, are complemented by contemporary ones from East Asia, which stand on somewhat shakier ground: the expansion of Sōka Gakkai, an exclusivist lay Buddhist association, in Japan from less than 6,000 households in 1951 to around eight million in 1995, and the conversion of students in 1980s Singapore from Buddhism or Chinese popular religion to either Christianity or Islam (ibid.). For one thing, these are still ongoing processes, and for another, in neither case can the exclusive groups be said to have achieved a dominant status. Further testing of the hypothesis is therefore required. 
The argument that exclusive religious groups win out over non-exclusive ones must be viewed against the backdrop of the 'supply-side model' developed by the religious economists. The gist of the argument is that changes in a religious economy are induced not by alterations in religious demand - the conventional explanation of religious change -, but by the appearance of new religious competitors and hence by shifts in religious supply. Although this model has been tested empirically (e. g. Bruce 2000, Jagodzinski and Greeley, no date, Greeley 1998), such tests have been limited to Western Europe and the USA. To the extent that the supply-side model aspires to be universally applicable, other world regions need to be taken into account.

In what follows, I will test the supply-side model by taking a look at the history of conversions to Protestant Christianity in China in the nineteenth and early twentieth centuries. In so doing, I will provide an example of how - to paraphrase Stark and Finke - an exclusive religion performed in a largely unregulated context. The focus of this paper will be on the period when evangelization was dominated by foreign missionaries, but developments in the post-missionary era after 1949 will provide a point of comparison, as will movements at the fringes of Christianity, such as the Taiping religion.

In confronting the supply-side model with what empirical evidence on the history of Protestant Christianity in China has been assembled over the past few decades, I wish to engage the existing research context in various ways. First, as should have become clear, I intend to proceed from the phenomenon for which the religious economy approach was originally conceived - Christianity in North America and Europe - by placing it in a different context, namely the Chinese religious field. Second, I try to avoid an a priori critique of the religious economy approach, as many of its opponents have done (e.g. Bruce 2008, Voas, Olson and Crockett 2002, Bryant 2000). I consider such a critique difficult as many of the theoretical assumptions of the religious economy approach are axiomatic in nature and hence impossible to falsify. Whether it is possible to subsume spiritual experience under the category of 'reward' or 'utility' is not a matter of verifiability. Neither am I predisposed against the way the religious economy model seemingly glosses over core values of religion such as devotion, zeal, selfsacrifice and compassion on the basis of theoretical assumptions otherwise associated with material gains. ${ }^{1}$ What I am interested in is the explanatory value of the 'supply-side model'.

Third, I wish to move away from previous applications of the religious economy model to a Chinese context, not only in that unlike their authors, I do not regard this model a priori as an accepted one, but also in abandoning their focus on contemporary issues. Not coincidentally, perhaps, the majority of existing studies (Lang, Chan and Ragvald 2005, Lu Yunfeng 2005 and

1 I am drawing here on discussions at the two conferences mentioned in the introduction to this volume, as well as on the comments of an anonymous reviewer on an earlier version of this paper. 
2008, Yang Fenggang 2006, Yang and Tamney 2005) deal with the reform period after 1978 when China was being transformed into a 'socialist market economy'. By contrast, I attempt to shift attention to the late Imperial and early Republican periods, providing a historical dimension that only a minority of studies has explored (McCleary and van der Kuijp 2010, Seiwert 2003).

In particular, this paper addresses the following questions: To what extent can the religious economy model explain the early history of Protestantism in China in general? In particular, can the supply-side model explain conversions to Protestant Christianity and does the history of Chinese Protestantism bear out the hypothesis about the greater competitiveness of exclusive religions? Is there a necessity to move 'beyond the market' with regard to China, and if so, what could this move look like? To be able to answer this question, it is important that we look at the basic assumptions of the 'supply-side model' in the first place. Since it is probably less well known than the basic assumptions of the religious economy model in general, it merits a brief discussion.

\section{Applying the supply-side model to the study of Protestant Christianity in China}

Published in 2000, Acts of Faith, co-authored by Stark and Finke, is the synthesis and culmination point of at least a decade of research by the two authors, their long-time associate, Laurence Iannaccone, and others (e. g. Stark 2003, Finke 1998, Stark and Iannaccone 1994, Finke and Iannaccone 1993). It provides a general theory of religious economies in the form of the 'supply-side interpretation', which can be viewed as the result of a certain terminological and conceptual shift in the 1990s that constitutes a partial move 'beyond the market' as the economic foundations are expanded and enriched with social and cultural concepts (cf. Stark and Finke 2000: 194). Although the 'supply-side model' is formulated with explicit neglect of "[religious] economies consisting of nonexclusive firms" (ibid.) - in other words, most polytheistic societies -, Stark and Finke make it clear in other sections of their book that they consider their model to be universally applicable. Therefore I assume that the basic concepts of the 'supply-side interpretation' can be legitimately tested with regard to China as well.

According to the 'supply-side model', overall religious demand is relatively stable, with the religious economy divided into market niches comprising people with similar religious interests and preferences. These niches are held together less by social status than by the effect of common socialization (Stark and Finke: 197-198). Religious change is not viewed as the result of a changing demand structure, but rather as a consequence of transformations on the supply side as religious groups begin to occupy additional or different niches (Stark and Finke 2000: 193- 
196). These shifts, in turn, can be attributed to two fundamental assumptions of the religious economists, which were developed in their earlier works: First, religious groups operate like firms, i.e. they market their religious "brands", seeking to maximize their gains in terms of members and funds and thus competing with one another on a religious market (Iannaccone 1998: 1484-1485; Finke 1998). Second, according to the fundamental axiom of the religious economy model, human beings "seek what they perceive to be rewards and try to avoid what they perceive to be costs" (Stark and Bainbridge 1985: 5; cf. also Stark and Finke 2000: 100). Thus religious actors will look for rewards, both this-worldly and otherworldly ones, on the basis of a 'rational' analysis of costs and benefits (Stark and Finke 2000: 51-52, 88-89). ${ }^{2}$ This means that they compare the amount of "material, social and psychic costs of belonging to a religious group" (ibid.: 144). People do not necessarily prefer the 'cheapest' alternative, but are willing to pay higher prices for commensurate returns. In particular, two sets of costs are of interest: The first arises from the relationship with one or several gods, defined as patterns of exchange. An exclusive exchange relationship with one god tends to be more extensive and demanding, on the other hands, it offers more valuable (and other-worldly) rewards, in particular life after death (and not only a next life) (ibid.: 97-100). Stark and Finke follow Durkheim (1915: 42-50) in distinguishing between religion and magic. Departing from (and somewhat simplifying) Durkheim's distinction, they define the former as the relationship between humans and gods, the latter as the manipulation of supernatural forces without reference to (a) $\operatorname{god}(\mathrm{s})$ or to general explanations. This is also important because magic can neither generate extended patterns of exchange nor lead to forming a religious organization, being provided to individual clients instead (Stark and Finke 2000: 104-106). The second set of costs arises from the level of tensions between religious groups and the rest of society, which I am going to discuss in more detail shortly.

It is against this backdrop that conversions take place. Conversions are defined by Finke and Stark as "shifts across religious traditions" (Stark and Finke 2000: 114), a definition that I adopt for the purpose of this article. They are conceptually opposed to reaffiliations, which by definition take place between different strands of the same religious tradition (ibid.). Of the two processes, reaffiliation is the easier and hence more frequent one, since it allows people to bring in much of their acquired religious capital - their knowledge and mastery of a particular religious culture - into their new affiliation (ibid.: 120-124). In the process of conversion, Stark and Finke

2 It is interesting to observe that the term 'compensator', defined as "a belief that a reward will be obtained in the distant future or in some other context which cannot immediately verified" (Stark and Bainbridge 1985: 6, cf. id. 1979), has disappeared from the religious economic vocabulary in 'Acts of Faith', possibly because of its pejorative overtones. Note, however, that the concept of put-off rewards itself has been retained (Finke and Stark 2000: 88). By the same token, 'utility', another important term in earlier works (cf. Iannaccone 1998: 1479) is also conspicuously absent in the more recent book. It is important to note, also, that Stark and Finke (2000: 41) have rejected the label of 'Rational Choice Theorists'. 
(as well as Stark in his earlier, single-authored work on Christianity) have highlighted the importance of networks. This means that individuals' choice of religions is not an isolated process, but is informed by what people in their social environment (such as friends, neighbours, or spouses) choose (ibid.: 116-118, 125-138). The notion that religious niches are to some extent based on common class status, but more commonly on shared (patterns of) socialization, links the idea of conversion through networking to that of a religious market composed of demand niches.

Against this background, the 'supply-side model' goes on to argue that the relationship between religious groups and society at large is a crucial factor in religious change. New religious groups usually emerge as 'sects' ${ }^{3}$ characterized by a high tension with society, as both recruiting and monitoring are easier for small organizations (Stark and Finke 2000: 205 ff.). This tension arises from a religious group's strictness, i. e. its maintenance of a distinctive lifestyle and morality in both religious matters and everyday life (Iannaccone 1994: 1190). By applying "penalties and prohibition", groups may increase their members' commitment - which Stark and Finke define as the degree of meeting exchange obligations towards a god as defined by a given religious organization - as well as rates of participation and eventual net benefits for their members (ibid.: 1187, 1183, cf. Stark and Finke 2000: 103). This is possible because their high standards exclude or deter all those 'free riders' who want to enjoy the benefits of religious goods without contributing to their production gives them an edge over their competitors. To ensure growth and hence to be successful, religious groups must find the appropriate level of tension - "strict, but not too strict", as Rodney Stark (2003: 262) has formulated. On the one hand, they need an effective and legitimate authority capable of enforcing decisions that are accepted by the members; on the other, the more they maintain a cultural continuity with pre-existing religious traditions - also defined as cultural capital as opposed to religious capital -, the more successful they will be (ibid.: 261-262, 264-265). ${ }^{4}$ Accordingly, high-tension groups lowering tensions to a medium level are able to occupy larger niches and expand their membership (although they will cease to do so if tensions are reduced further); at the same time, their growth will lead to tensions and schisms (Stark and Finke 2000: 205-207, cf. Stark and Bainbridge 1985: 19-25).

3 Thus another important distinction, that between cult and sect, has also disappeared. Both were understood as deviant religious communities; however, cults, were thought to be situated "outside the conventional religious tradition(s) of a society" (Stark and Bainbridge 1997: 104; cf. also Stark and Bainbridge 1979 and 1985: 24-26, Stark 2003: 261-262, which latter was originally published in 1996), while sects exist within these traditions. In terms of China, Protestant Christianity in the early nineteenth century would have constituted a cult, as would Buddhism at the time of its first appearance more than a thousand years earlier.

4 The distinction between 'religion' and 'culture' seems to be meaningful here, wherefore I have added the emphasis. The alternative term of 'cultural capital' (Stark 2003: 261) seems to suggest a loose cultural framework rather than the transfer of knowledge and mastery of a religion as suggested in Acts of Faith. 
In the following, I will apply this conceptual framework to the study of Protestant Christianity in nineteenth and twentieth-century China. For centuries, Chinese religions have been characterized by fluidity and overlaps rather than clear-cut boundaries. And although some Chinese religions (such as monastic Daoism and Buddhism) can be viewed as institutionalized, they have become enmeshed in the web of what C.K. Yang (1961) has called "diffused religion" and what is generally referred to as popular religion. In Chinese popular religion, religious activities are carried out by the basic social institutions such as family, village or descent group or by individuals within the framework of these institutions. At the same time, the relative vagueness of inter-religious boundaries in China has led to exchange, appropriation and fusion, be it in new forms of syncretistic religion (Berling 1980), the idea of the unity of the Three Teachings of Confucianism, Daoism and Buddhism (Gentz 2006) or the eclectic borrowing from a wide array of traditions in Chinese popular religion (Brook 1993).

In late Imperial China, the government banned 'heterodox' (xie 邪) religions, and its Republican, Nationalist and Communist successors since the Revolution of 1911 pursued an even more interventionist religious policy (Liu Kwang-ching 1990, Liu and Shek 2004, Duara 1991, Gossaert 2006, Nedostup 2010, Wang Xiaoming 2003, Luo Zhufeng 1991, Potter 2003). But with the possible exception of the early People's Republic between 1949 and 1976, much of religious policy was utilitarian, and even when the government favoured one particular religion as was the case with Confucianism in Imperial China -, others were tolerated, so there was always a remarkable degree of religious pluralism. As will be shown in more detail below, the Qing dynasty (1644-1911) had outlawed Christianity (in its Catholic form) in 1724, which effectively barred Protestants from entering China. But after Protestantism, along with Catholicism, had become a lawful competitor in the mid-nineteenth century, missionaries were at least formally free to evangelize at will.

The structure of this paper will follow the theoretical outline given above. As befits a discussion of the 'supply-side model', I begin with a discussion of the 'suppliers', i.e. the missionaries and the organizations that sent them to China, looking in particular at the ways in which they recruited converts and at the institutional arrangements they set up. In a second step, I shift the perspective to the 'demand side', analyzing the patterns underlying Chinese conversions. The third section looks at Christian congregations in China as 'strict churches' and examines both the attempts of the missionaries to subject the Chinese Christians to a rigid church discipline and the ways the latter sought to deal with the exigencies of Christianity. Much of the empirical material is drawn from my research on the Basel Mission and its Hakka Church in Southern China, which is fairly representative of a rural Chinese church founded by pietist or evangelical missionaries; however, I have supplemented this material with other contemporary 
missionary publications, statistical material and findings from other studies in order to gain the broadest possible perspective. In the concluding paragraphs, I will return to the theoretical issues and discuss the value of the 'supply-side model' for explaining conversions to Christianity in late Imperial and early Republican China.

\section{The missionary framework for conversions}

Any discussion of the history of Protestant Christianity in China must begin with the political framework which enabled it to 'supply' the Chinese with a largely (though not wholly) new form of religion. Unlike the Catholics, early nineteenth-century Protestant missionaries were absolute newcomers to China. But the ban on Catholicism issued and enforced by successive emperors of the Qing dynasty (1644-1912) in the eighteenth century as a consequence of their conflicts with the Vatican applied to Protestants as well, so they were not free to reside within the borders of the Qing empire, let alone evangelize there (Su Jing 2005: 11-12). It was therefore only after the 'unequal treaties' and toleration edicts of the 1840s to 1860s, which the 'Western' powers had forced on the Qing empire, had legalized the residence and evangelizing activities of 'Western' missionaries in China that missionaries could establish themselves in the interior of China. By 1900, there was hardly a district without at least a handful of mission stations (Feuerwerker 1976: 39). The missionaries' right of abode was complemented by several toleration edicts, likewise wrested from the Qing government, which exempted Chinese Christians from contributions to 'heathen' rituals (Tiedemann 1996: 389). Within this new legal framework, Christian missions could lawfully compete with other religions, and what is more, it could do so on its own terms. Without any political or legal need for compromise with any form of Chinese religion, the approach of nineteenth-century missionaries had little in common with the strategy of accommodation developed by the early modern Jesuits - although even this strategy was perhaps less compromise-oriented than has long been assumed (Brockey 2008, Standaert 2001, Gernet 1985).

And competition did lie at the heart of the Protestant mission enterprise in China as elsewhere. Evangelization was tantamount to convincing the Chinese of the superiority of Christianity over all indigenous forms of religion. This attitude reflected the dichotomic worldview of most missionaries, who perceived 'good' and 'evil', 'light' and 'darkness', God and Satan as being locked in a permanent struggle - although it was clear to them that the ultimate victory belonged to God and his children. In addressing Chinese people, missionaries strove to convince them that they were sinners in need of salvation, that Jesus Christ had redeemed them 
to the grace of God and that they were to believe in him and accept his sacrifice to be saved from damnation. This was the missionaries' message put in a nutshell; to transmit it to their audiences, they relied on a number of techniques, some of which were direct and others indirect. Dominant in the former category was (often itinerant) preaching, which was based on the assumption that the truth of the Christian message was plainly intelligible to human reason; moreover, there existed a 'natural theology' that, unbeknownst to themselves, the missionaries' listeners also were familiar with (Klein 2002: 166-169). Preaching could take place in more formal or rather informal settings. A rather casual strategy employed by female missionaries on house-to-house visits (because Chinese women did not usually appear in public) was called 'gossiping the gospel' (Austin 2007: 4-5), but male missionaries held similar meetings with Chinese men at their mission stations. Visual material was employed to support the verbal message, but was also put on display independently so as to arouse the interest of passers-by and to attract them to the Christian message (Klein 2002: 166-167). The China Inland Mission and the Church Missionary Society, two of the largest organizations, adopted a device called the 'Wordless Book', which consisted in four pages of plain colours to explain God's plan of salvation, and which inadvertently played upon the Chinese symbolism of colours evident in the cosmological cycle of the Five Elements (wu xing 五行), where every element and developmental phase is associated with one specific colour (Austin 2007: 2-11, 86-90).

Such techniques partly helped the missionaries in circumventing the obvious linguistic problems they were facing. Since missionaries arriving in China took time to acquire the linguistic skills necessary to preach and converse effectively and only a minority of them came close to Chinese standards, practically all mission societies resorted to employing Chinese assistants, who played an invaluable role in spreading Christianity (Lutz and Lutz 1995). A related problem that was more difficult to remedy (and also required Chinese assistance) was that of creating a Christian language and terminology that would appeal to the Chinese without compromising the theological concepts espoused by the missionaries. This was evident in oral communication, but even more in the translation of the Bible into Chinese. Controversies over the appropriate name for God or the problems surrounding the translation of the word 'sin' - a concept hitherto unknown in China - are the most prominent examples, but are only indicative of a broader trend (Zetzsche 1999, cf. Eber 1999, Li Tiyuan 1995).

Linguistic intricacies certainly did not deter the missionaries, but probably contributed to the development of more indirect strategies, in particular medical mission and education. Both had their roots in the first decades of the nineteenth century. Many missionaries offered medical treatment, but over time the service became more professionalized, with trained physicians taking over and establishing hospitals. They provided health care for their fellow missionaries, but more 
importantly spread 'Western' healing methods throughout China, offering effective treatment and helping to train a modern Chinese medical elite (Cohen 1978: 574-576, Minden 1994, cf. Yip 1995: 19-22). In addition to being cured of physical illness, patients were regularly addressed or preached to by missionaries or Chinese evangelists. Education was even more intimately connected with the effort to spread the Gospel, as the missionaries hoped it would shatter what they considered one of the bedrocks of paganism - ignorance (e. g. Lechler 1877:162). At a more pragmatic level, mission schools and universities became training institutions for Chinese assistants and theologians, in other words for the future leadership of the church. Once the Chinese state had removed the barriers for the full recognition of mission-school education in the early twentieth century, the massive influx of more secular-minded students made it difficult for mission schools to maintain their Christian character, especially in higher education (Rosenbaum 2006: 28-29, 42-44; cf. Wang Dong 2007: 39-42).

Protestant missions thus made use of a wide array of strategies and techniques attractive to the Chinese, and in so doing, were driven by a sense of competition with indigenous forms of religion. However, this did not mean that people who were attracted to Christianity through these efforts were easily admitted into the congregations established by the various mission societies. On the contrary, missionaries insisted that converts receive instruction in the basic principles of Christianity. This usually meant that they had to be able to memorize a number of essential texts such as the Lord's Prayer, the Ten Commandments and the Apostles' Creed, after which they were admitted to baptism. It was crucial for the missionaries to reserve the right to baptize for themselves (Cheung 2004: 64-82). With the exception of a few outsiders such as the German free missionary Karl Friedrich August Gützlaff (1803-1851) with his strategy of blitz conversion, most 'Western' missionaries were going for quality rather than quantity, concentrating on a "selected few” (Cheung 2004: 83, 86; cf. Lutz 2008: 227-228, 247-249).

From the missionary viewpoint, baptism constituted a rite de passage in two ways: It marked a clean break with the converts' pasts, both in terms of religious affiliations and socio-cultural habits, and it initiated them into a new type of religious community, the Christian congregation. With few exceptions, such as the above-mentioned Gützlaff and the China Inland Mission prior to 1900 (Lutz 2008: 220-228, Austin 2007: 440-443), the majority of missionaries seem to have favoured a process that mirrored their own socialization into Christianity in the 'West': In the tradition of evangelicalism, pietism and revivalism, conversions were expected to individual processes of inward spiritual transformation, although even most missionaries had hardly experienced a dramatic and sweeping revolution in their religious biographies as postulated in revivalist rhetoric (cf. Altena 2003, Jenkins 1978). At any rate, conversions of Chinese needed a social framework, and congregations were a quasi 'natural' way to provide the latter. 
Most missionaries were sufficiently realistic so as to distinguish between the formal act of joining the Christian church on the one hand and true spiritual rebirth on the other. Hence they perceived congregations as a form of organization that contributed significantly to inculcating in the indigenous converts a Christian way of life that comprised changes not only of their external behaviour, but also of their spiritual development. Congregations thus also provided an institutional framework for monitoring Christians and to make sure that they did not stray from the right path. This was considered all the more necessary as the Christians formed a tiny minority in an otherwise 'heathen' society, a point which I will explore in more detail in the third section. Christian congregations were not set up independently, however, but they were incorporated into the organizational framework of the respective mission societies.

Most mission societies also set up more or less formalized guidelines to direct their converts' religious lives. Clearly written rules might not necessarily advance the Christians' spiritual development, but they might instil in them the mores and behaviour expected of a true Christian or at least prevent them from relapses into paganism. Regulations did not prescribe social segregation, but exhorted Christians to abstain from any 'heathen' practices, in particular religious practices. Thus the Chinese translation of the charter drawn up by the Swiss-German Basel Mission carefully listed the religious practices forbidden for a Christian:

"If there are those who inquire after baptism to enter the mission and have to do with the affairs of evil gods, they must do away with them, no matter whether openly or secretly, they must not engage in them. [...] Those who have been baptized into Christ's death or wish to be baptized may not perform the jiao 醮 [a Daoist purification ritual, T.K.] nor keep the holidays for graves and ancestors (shoujie shanfen, zugong 守節山墳、祖公). All techniques to ward off evil influences are doings of the heathen (yibangren 異邦人). It is not proper for members of the mission (shenghuiren 聖會人) to use them, therefore they ought to be abolished. Eight Trigram divination (bugua 卜卦), fortune telling, geomancy and chronomancy (dili zeri 地理擇日), questioning the immortals, contacting a medium, exorcising demons and writing charms are all dark deeds, the children of God may not emulate [those who perform them]" (Base Shenghui Guitiao 1874, 1-3, translated by T.K.).

This list indicates how Protestant missions such as the Basel mission were strict societies in the sense of the supply-side model in that they adopted an uncompromising attitude towards all forms of local Chinese religion. For Christians, this entailed a clean break not only with their former religious life, but, more importantly, with the ongoing religious activities of their kin and neighbours. There was some debate to what extent missions ought to interfere with practices that 
were not religious; however, there seems to have been a widespread consensus that missions should work towards abolishing not only "idolatrous" customs, but also practices that were not religious in nature, but "cruel" or "vicious" or at least leading to vice. These included polygamy and child marriage, infanticide, gambling and feuding (Ohlinger 1890, 605-608; Noyes 1890, 610). To fully appreciate the magnitude of this task that the missionaries had set for themselves, we must first understand what brought Chinese people to the Christian church.

\section{Conversion to Christianity from a Chinese Perspective}

I will begin my discussion of conversions to Christianity in late nineteenth and early twentiethcentury China by looking at the statistics, which the various mission societies (both Protestants and Catholics) were meticulous in keeping. In the late 1870s, there was a total of about 13,000 Protestant Christians in China (Records of the General Conference 1878: 486). The great statistical survey undertaken by the China Continuation Committee - an interdenominational and mixed 'Western'-Chinese organization founded in 1910 (Latourette 1929: 671) - yielded about 235,000 communicants for 1914 and a figure of 366,000 communicants only in 1920, although it generously placed the total Christian constituency at almost twice that number - including those "under Christian instruction" - and pointed out that the number of Christians had more than tripled since 1900 (Stauffer 1922: 38, 293). With the Chinese population estimated at more than 452 million in the same publication, only one in around 1,300 Chinese was a Protestant Christian (ibid.: 298). A sidelong glance at the Catholics yields a comparable trend (cf. Streit 1906: 10-11). Eighty years after the first unequal treaties, Christianity was still very much a minority religion, with most Christians living in the countryside (Tiedemann 2001: 110). ${ }^{5}$

That the overwhelming majority of the Chinese saw no reason to convert to Christianity begs the question, of course, why a minority did. For a long time, researchers have focused on the Christians' economic and socio-political motives (e.g. Esherick 1987: 77-78), and in so doing they have been echoing an anti-Christian tradition in China that dates back to at least the 1920s (for a wider context cf. Stanley 1990: 11-30). Only more recently have anthropologists and historians begun to appreciate the religious motives behind conversions to Christianity (Jordan 1993, Dunch 2001, Tiedemann 2001, Klein 2002). This should not blindfold us against the secular dimension of converting to Christianity, as will become clear in the subsequent discussion, but it clearly has led to a more comprehensive and differentiated understanding of this process. The bulk of material comes from the missionary side. Missionaries had a vested interest in recording

5 It is for this reason that my analysis largely excludes the urban, often more liberal, sector of Protestantism. 
and publishing conversion stories, since they legitimized and justified their efforts, allowing them to portray 'model' Christians and stimulating fund-raising. Their accounts of conversions and the motives underlying them thus have to be treated with the necessary cautions.

Let us turn to the religious dimension first. This has to be examined against the background of the complex set of religious concepts and practices conventionally subsumed under the label popular religion or folk religion. A detailed examination would go far beyond the scope of this article. Suffice it to say that historically, Chinese popular religion has encompassed the relationship between humans and different kinds of transcendent beings - "gods, ghosts, and ancestors" (Jordan 1972, Wolf 1978) - as well as techniques to ward of evil influences, a number of which are listed in the above quotation from Base shenghui guitiao. Religious activities have been performed in various social frameworks: at the communal - i.e. villages, village alliances and descent groups -, family and individual levels. They also have been conducted at various places such as homes, temples, ancestral halls and graves.

This complex whole might in part - though, I think, not in its entirety - be described as a 'religious gift economy' that involved not only dyadic relationships, but also more indirect chains of exchange (cf. Palmer, this volume). To the extent that the former was the case, we may follow Jordan Paper (1995: 47-50 and 1987) in identifying sacrificial rituals in which - to put it simply offerings were exchanged in return for protection as the core of Chinese popular religion. Key to this reciprocal exchange has been the concept of efficacy (ling 靈) or, more precisely, that of miraculous responses (lingying 靈應) to worshipers' requests (Chau 2006: 2; cf. Brook 1993). The degree of flexibility this framework allowed depended on the way the relationship with gods, ancestors and ghosts was perceived. Ghosts were treated as generically evil (and therefore summarily 'bribed' for doing no harm rather than supplicated for positive protection), ancestors as generally good, while gods were thought of as more powerful, but also as less dependable than ancestors (Lagerwey 2000: 5-6). This latter relationship was therefore the most flexible, allowing for shifting allegiance to one or more powerful and efficacious deities and even for sanctions if divine protection was not forthcoming. Activities such as exposing the statues of deities to sunshine and heat or of 'lashing the dragon pond' (da longtan 打龍潭) in order to disturb the Dragon King of the Sea (bailongwang 海龍王), a deity specifically associated with providing rain, as measures of coping with droughts have been recorded by both missionaries and anthropologists in different regions of China (Smith 1899: 172, Stenz 1906: 863; Chen Jiasheng 1997: 440). Given the volatile relationship with the gods, it comes as no surprise that in general, missionaries considered ancestor worship the greater obstacle to Christianization (cf. Yates 1878: $5,45)$. 
The same focus on efficacy with which the gods have been treated has also guided the selecting and hiring of specialists providing various techniques of warding off evil and mobilizing positive influences, such as fengshui 風水 or various forms of divination (subsumed under 'magic' in the religious economy model as shown above). It almost goes without saying that this too has been a highly flexible (and competitive) process that allowed clients to go for whatever they have perceived as the best quality (e.g. Goossaert 2007: 240-263, Bruun 2003: 5-6, Fan Wei 1992, Hayes 1985). It has also allowed a procedure of trial and error to find the appropriate method (for an example cf. Lutz and Lutz 1998: 90).

To efficacy, reciprocity and flexibility (as well as competition), we must add a last defining feature of Chinese popular religion: Although it addresses the relationship between the living and the dead, it has been primarily concerned with this-worldly as opposed to other-worldly rewards. ${ }^{6}$ Both gods and ancestors and religious specialists have been approached for matters of health, offspring, rain - crucial in the largely agricultural society that was China at least up until the close of the twentieth century - success in business or the state examinations (as the main path to social advancement in late Imperial China), assistance in difficult decision-making, and the like.

This was the background against which, if we are to believe the conversion stories recorded by missionaries, many Chinese were attracted to the Christian message. Personal hardships and crises often triggered this process: The death of close relatives, impoverishment and other mishaps caused people to search for the causes of their misfortunes and to look for the appropriate remedy. If help was not forthcoming from the established sources - gods, ancestors or religious specialists -, people might take a chance with the Christian god. If the latter proved to be effective in bringing about a change of fortune (Jordan 1993: 293), they might cast their lot with him (Klein 2002: 194-197; Najarian 1982: 83-85). In this context, effective treatment of diseases by missionaries provided a powerful incentive to become a Christian.

'Seekers after truth', as the missionaries called those who inquired after the Christian message (Tiedemann 2001: 116-117), also came from a very different quarter of the Chinese religious field, namely from lay groups often referred to as popular religious 'sects' (for problems of terminology cf. ter Haar 1992: 11-15). Like the Christians, these groups relied on sacred texts (baojuan 寶卷), some of which reflect the Buddhist concern of how to free oneself from the cycle of rebirth (sansāra), while other traditions provided the means to escape imminent cataclysms (Overmyer 1999). Structural parallels in organization, but also in rhetoric, facilitated the shift of 'sectarians' to Christianity (cf. Austin 2007: 68-69, 376-378, cf. Bays 1983, 1985 and 1991); after

6 This terminology is not confined to the religious economy model. A similar terminology, substituting 'rewards' with 'goods' - an explicit echo of the Weberian concept of 'salvation goods' or Heilsgüter - is used by Stolz 2008: 61. 
all, they came from a background where religious groups were led by entrepreneurial types and where competition as well as shifts from one group to another were common (Tiedemann 2001: 116; cf. Seiwert 2003: 445-454; Gaustad 2000: 19-21).

Having discussed the religious dimension of conversions, I next turn to economic incentives. In contrast to the earlier emphasis on the so-called 'rice' or 'millet Christians', recent studies have demonstrated that converts actually came from a very mixed social background and included a not insignificant number of members of the rural elite, landlords and local literati, i. e. degreeholders who had passed the lower state exams and were thus qualified to hold office (Tiedemann 2001: 118-120; Klein 2002: 199). This is not to say that nobody ever converted for economic reasons; quite the contrary. However, the economic argument needs some qualification. It has often been particularly emphasized, for example, that converts sought employment with the mission (Tiedemann 2001: 118-119, Najarian 1982: 86-88). However, the prospects of succeeding were not too bright. According to the Protestant survey of 1918-1921, an average 7.3\% of church communicants were employed as evangelists, teachers and medical personnel by the mission societies in the 19 provinces of China, with figures going up to between 11.2 and $12.3 \%$ in Hunan, Sichuan and Anhui (Stauffer 1922: 291). ${ }^{7}$ As the statistics for the one province of Guangdong in the same survey show, the ratio of employed communicants could vary: Whereas the provincial average was only $4.7 \%$, individual mission societies reported a figure of up to $13 \%$ (ibid.: 166). Even adding those who were employed in the households of the over 6,500 missionaries (ibid.: 287) as cooks, nursemaids or servants, the official figure of around 25,000 Chinese employees would probably not more than double. In total, then, one out of seven communicants ended up in the service of either mission societies or, privately, in that of the missionaries. Although might be assumed that the proportion of employed agents was greater in the early years of Protestant missions, figures from the 1870s are surprisingly similar (Najarian 1982: 86).

Missionary help might take other forms, however. For example, Christian congregations sometimes held land which they rented out to church members; moreover, missionaries were a source of cheap credit, which was always in high demand in Chinese rural society, with money usually being lent at horrendous interest rates and a high proportion of peasant households in serious debt (Klein 2002: 200-201; cf. Tawney 1932: 58-63, Osterhammel 1997: 176). Christian missions also engaged in famine relief, most notably during the great North China Famine of 1876-1879, and in their efforts partly competed and partly collaborated with Chinese networks

7 The one noteworthy exception was Xinjiang (at the time a Special Administrative District), where the ratio of employed workers reached $48 \%$ of communicants, but this was due to low membership figures. 
(Edgerton-Tarpley 2009, Lee 2009). Both after this famine and a subsequent one in 1889, the number of converts in areas of North China increased significantly (Tiedemann 2001: 120-121).

Another kind of economic incentives has more recently come under scrutiny: The Christians' exemption from 'idol taxes'. Communal religious activities, in particular festivals in honour of deities (and the local operas that were a standard feature of such festivals), were regularly financed by contributions from villagers. After the toleration edict of 1862 had freed Christians from this obligation, many of them did in fact refuse to pay their share (Austin 2007: 158-160, 257; Tiedemann 2001: 119). There is evidence that Chinese preachers used this effective reduction of the Christians' financial burden as an argument to attract non-Christians to the message of the Gospel. It is all the more credible because the missionaries who recorded this practice openly disapproved of it because it appealed to the allegedly 'materialist' outlook of the Chinese (Klein 2002: 201).

Finally, I shall examine the socio-political motives. For the most part, these were based on the missionaries' ability to act as local power brokers, for which the unequal treaties in conjunction with the Imperial toleration edicts provided the legal framework. Strictly speaking, the former only protected foreign nationals, whereas the latter sanctioned the persecution of Christians on account of their religion. In practice, whenever missionaries could prove that a 'persecution' of Christians had taken place, they were able to secure the support of the Chinese authorities and, if these proved unwilling, to the diplomatic representatives of their native countries. This enabled the missionaries to wield considerable power at the local level, especially against the background of the local 'culture of violence' that was a constant feature of rural life in nineteenth-century China and beyond (Tiedemann 1998; cf. Bianco 2005, Lamley 1990 and 1977). Both inter- and intra-communal conflicts between villages and/or descent groups over scarce resources were the order of the day, with government officials often reluctant to interfere. Missionaries, however, were not hesitant to mobilize the Chinese state in support of their and their Christians' interests.

In a society in which 'strong' communities recklessly used their resources of fighting men as well as their financial reserves against 'weak' ones, conversion to Christianity provided disempowered groups with access to a new source of strength, thereby reversing existing power relations. The more missionaries demonstrated their capability of holding both the state and stronger communities in check, the more consciously their protection was sought after. By the 1890s, this had developed into a sophisticated strategy in which rivalling communities made use of the divide between Protestants and Catholics in order to mobilize an external source of power to support them in their conflicts. Christianity and the international politico-legal framework in which it operated in China were thus functionalized for local power games (Klein 2005: 285-294, Lee 2003, Jörgensen 2001). It was only after the Boxer Uprising had made both mission societies 
and Chinese officials more wary of the dangers associated with this strategy that steps were taken to ease tensions rather than fuel them.

Having discussed the main motives for conversion, I wish to add two general characteristics that unite almost all of them: First of all, joining Christianity in general was the result of individual decision. Sectarians often converted in groups (Tiedemann 2001: 117), and in some localities, the drive towards Christianity took on the character of a social movement (Klein 2002: 205). However, in the latter case it is doubtful if this was more than an aggregation of individual conversions, although local or kinship ties clearly facilitated the process (Lutz and Lutz 1995: 218-220). The best indicator for the individual character of conversions in China is that, notwithstanding the overall importance of the family in both Chinese culture and society in missionary strategy, families rarely converted as a whole. As late as 1922, the China National Christian Conference sought to develop a strategy to "win the family to a greater degree than the present would indicate" (quoted in May Chen 1998: 176). In particular, there is evidence to suggest that women, although assigned a socially inferior role, were under no obligation to convert along with their husbands. On the other hand, it was almost impossible for a married woman to convert without the consent of her husband (Klein 2002: 206-207). The result was a surplus of Christian men in the late nineteenth and early twentieth centuries. After more than a half-century of hard work to win over females to Christianity, the survey of the China Continuation Committee still yielded an average of $63 \%$ male communicants in all of China (Stauffer 1922: 293).

Second, regardless of whether they were driven by religious or secular motives, Chinese converts were steeped in the concepts and traditions of Chinese religions, in particular popular religion. This had important consequences for their conversions. As David Jordan has stated on the basis of anthropological fieldwork, conversion to Christianity is conditional upon pre-existing beliefs, and it is additive, which means that new beliefs do not replace older ones, but are grafted upon them (Jordan 1993). This becomes very clear as we look at cases where the Christian god was incorporated in the existing pantheon - and which missionaries and Chinese evangelists sought to suppress - or where Christian missionaries were invited as religious specialists to perform rainmaking ceremonies (Lutz and Lutz 1998: 191, Klein 2002: 192-193). One wonders whether the term 'conversion' is appropriate at all, as neophytes - at least initially - tended to experience Christianity not as a new religion, but as a new option within their wonted religious framework. Thus it not only took them a long time to develop a Christian identity, making conversion a process rather than a datable experience in the evangelical or pietist sense (Lutz 2008: 7-9); even more critically, the outcome of this process was not necessarily congruent with 
missionary expectations. This was to have consequences for the emergence of a Chinese Christianity, to which we now turn.

\section{Strict churches or negotiated Christianity?}

From the above discussion it should have become clear that conversion to Christianity was conceptualized in diametrically opposed ways by missionaries and Chinese Christians. Rooted in North American and European revivalism, evangelicalism and pietism, the missionaries had high expectations of both the spiritual depth and moral bearing of Christians, both in their native countries and in the mission fields. Missionary standards thus far surpassed those of the average North American and European Christians, who viewed their Christianity in rather formal terms. On the other hand, many if not all Chinese Christians approached their new religion against the backdrop of popular religion. The Christian god was measured against the yardstick of ling, and if he failed to deliver (or an alternative option proved more attractive), their membership in the church could be called into question, as in the following example:

"In Luogang [a village in Northeastern Guangdong] there was a Christian woman. Once she could not find her water buffalo and went to see a medium (tongshen 童神) [about this]. The medium said: 'You shouldn't have embraced the [Christian] teaching and gone to church. As for your water buffalo, it can be retrieved.' When the buffalo was indeed retrieved, she didn't go to church for a long time. The missionary and [Chinese] preacher specially went to exhort her, and she corrected herself and came back" (Zhang Zuji 1980 [1928-1934]).

The missionaries certainly were not blind to the extent to which Chinese Christians were willing to strike compromises between their new and old religions, and this was one of the reasons why they imposed on them a system of surveillance and sanctions. Church discipline was central to the mission effort (cf. Lechler 1890, Corbett 1890). As a rule, a wide range of possible sanctions could be applied, ranging from exhortation to exclusion from Holy Communion to outright expulsion from the congregation. In this attempt at strictly separating Christians from all forms of indigenous religions as well as from as number of cultural and social practices, mission churches differed radically from Chinese religious lay groups, which by and large exhibited a rather conservative outlook at state and society (Overmyer 1984 and 1999: 210-213). Although these groups shared with Christian missions a dichotomic division of mankind into the adherents of the group on the one hand and the indifferent majority on the other, sectarian groups seem to have kept a low profile and carefully avoided tensions with society at large (except when some of them occasionally rebelled against the government). For example, their members participated in 
'normal' religious activities of local communities (cf. Li and Naquin 1988), something that Protestant (as well as Catholic) missionaries would have found unthinkable.

The effects of the mission societies' disciplinary strategies had far-reaching repercussions, not only within the congregations, but also within society at large. To begin with, as missionaries did their utmost to enforce the strict regulations governing the mission congregations, there was some degree of fluctuation within the congregations. As the above example suggests, some Christians left the church of their own volition, but others were expelled by the missionaries. On the other hand, converts who complied with the rules could come under severe pressure from their non-Christian peers. Often they were held accountable for all misfortunes happening to themselves or, even worse, occurring in their neighbourhood (Klein 2002: 206). At the communal level, the refusal of Christians to participate in collective religious activities might lead to tensions, as these activities were only regarded as efficacious if all members took part. Tensions of this kind were one factor behind the so-called 'missionary cases' (jiao'an 教案), violent clashes involving missionaries or converts that had to be dealt with by the Chinese authorities and foreign diplomats. A number of well-documented jiao'an arose from Christians withholding contributions to temple festivals (Lee 2003: 149-153, Zhao Shuhao 2000: 66-67, Litzinger 1996). For the Christians, there was thus no easy way out of the established religious communities. On the other hand, given the general tendency in historical material to prioritize conflict over quotidian harmony - a bias reinforced in this case by the political framework and the actors' vested interests -, there is much to suggest that the Christian religion may not have been 'regarded as all that alien' and that 'the more common pattern of peaceful coexistence' simply has largely gone unnoticed (Tiedemann 2001: 108-109). This opens up a new perspective emphasizing the many links between Chinese Christians and non-Christians, which had farreaching consequences of the relationship between missionaries and converts and between Christian congregations and society at large.

Let me begin with the former and look at some statistical material first. To my knowledge, no synthesis of data on the practice of church discipline has been produced so far. I will therefore have to limit myself to spot-checks here. For the year 1920, the statistical survey undertaken by the China Continuation Committee mentions 85,140 baptized persons who were not communicants. Even if we assume that all of these were excluded from communication as a disciplinary measure (and this is impossible, since the category must have included a sizeable portion of children), the conclusion is that this form of medium-level disciplinary action was taken against a maximum of 18 per cent of all baptized Christians in that year (cf. Stauffer 1922: xci). More significant is a set of data on the exclusionary practice of the Basel Mission between 1880 and 1910. These data suggest that on a ten-year average, between one and 1.7\% of 
Christians were expelled from the congregations (Klein 2002: 241) - a remarkably low figure, given the fact that transgressions of the converts formed a large portion of what the missionaries reported back to their home boards. There are several possible explanations for this: The majority of Christians may have complied with the rules, but it is equally possible that the missionaries found it difficult to learn of violations. In the rural areas where the majority of Chinese Christians resided (cities were a different matter), the congregations which they supervised from central mission stations covered a vast territory, and even periodic visitations were insufficient to exercise tight control over Christians. Finally, it is possible that the missionaries did sense the magnitude of the problem, but regarded expulsion as an ultima ratio to be applied when all other means had failed. The ambiguity of the statistical material is backed up by the complexity of missionary discourse on Chinese Christians: Depending on the context, missionaries either construed the 'good' Christian as the diametrical opposite of the 'evil' heathen or distinguished between 'good' and 'bad' Christians or portrayed them as generically defective, pointing to their 'entanglement' with Chinese culture (Klein 2004: 40).

Occasionally, missionary sources do suggest that the influence of the non-Christian social environment on converts was greater than the missionaries were ready or able to admit. In the Basel Mission again, there is photographic evidence that Christians continued to wear a specific sort of charm against evil spirits, although this practice is hardly ever mentioned in the written reports of the missionaries (Klein 2004: 42-46). With regard to exorcism, which before the coming of Pentecostalism to China in the early twentieth century was viewed with scepticism in most missionary churches, Alvyn Austin has argued that it was a "secretive practice among Chinese Christians before it came to the attention of the missionaries" (Austin 2007: 262, cf. Lian Xi 2010: 27-31). Even when it did, they were circumspect in publicly acknowledging the fact (cf. Austin 2007: 262). It is therefore possible to conclude that the missionaries failed to notice some of the cultural fusions between Christianity and Chinese popular religion or glossed over them in their reports and publications.

In other cases, missionaries realized that they had to make concessions. After a lengthy discussion spanning more than two decades, the Basel Mission in the late 1890 allowed Chinese Christians to partake of sacrificial meat provided they were not present at the sacrifice itself. In justifying their decision, its missionaries referred both to the social conditions of Chinese local society and the rather ambiguous discussion of sacrificial meat in the New Testament (Klein 2002: 228-230). A much thornier issue was how to deal with polygamy and child marriages, practices rooted in ancestor worship (and the ensuing necessity to produce male offspring to continue the family line). In trying to suppress the former, the missionaries were walking on slippery ground because the independent study of the Bible as encouraged by the Protestants 
could bring Chinese Christians to the conclusion that polygamy was a legitimate practice, since they could find appropriate examples in the Old Testament (Lutz and Lutz 1998: 42, Klein 2002: 231, 338). Child marriages, on the other hand, had many economic and social implications and were transactions entailing mutual responsibilities for all parties involved. As missionaries who became more familiar with the local cultures of peasant China began to realize the complexities of the social life in which the Christians were enmeshed, they became more willing to strike compromises and to rely on an inward transformation rather than on externally imposed rules (cf. Records of the General Conference 1890: 656).

This does not mean that mission societies were ready to forgo church discipline altogether; what it does show is that part of the missionaries began to realize the opposing forces which were pulling at the mission congregations from two sides: Whereas the missionaries sought to maintain a state of high tension between Christianity on the one hand and Chinese religions, society and culture on the other, the Christians both from their own inclination and under the influence of their non-Christian kin and neighbours were ready to compromise. In the century or so that the churches were missionary-dominated, these forces remained in an uneasy equilibrium as the dynamics of evangelization pulled a small but steady stream of converts towards the Christian congregations. It therefore makes sense to view Chinese Christianity in the missionary era as a 'negotiated Christianity' that drew both on the missionary concept of 'strict churches' as on the entanglement of the Christians with local society and culture.

An assessment of the concept of 'strict churches' in China during the missionary era will benefit from a comparison with two related phenomena: A comparative glance at the Taiping movement may point the way Christian congregations would have developed without missionary control, whereas a brief examination of the indigenous Christianity that emerged in the early twentieth century will show whether the tensions between Christianity and Chinese society were maintained or eased as indigenous leaders increasingly took over from the missionaries.

The Taiping movement 太平 originated in the vision of Hong Xiuquan and his subsequent interpretation thereof, by which he established himself as the younger brother of Jesus Christ (Reilly 2004, Kuhn 1977). In order to promote, Hong founded an association called the God Worshipers' Society (Bai Shangdi Hui 拜上帝會), which grew from a few hundred followers of Hong in 1845 to several thousand members in 1851. In this year, following a number of clashes with the Imperial authorities, Hong proclaimed the Heavenly Kingdom of Eternal Peace (Taiping tianguo 太平天國) and became the founder of an ephemeral state in Central China that lasted until its destruction at the hands of the Imperial government in 1864. Part of the dynamics of the movement originated from the civil war situation in which this state-building effort took place and from the coercive measures which the government adopted. Most importantly, it organized 
the population into units of 25 families each under a sergeant whose duties included the supervision of communal religious activities. Thus conversion to the Taiping religion was not necessarily voluntary, and in fact the degree of faith and adherence to the movement varied across time and space (Reilly 2004: 117).

As a religious movement, the Taiping tianguo is hard to categorize. There is a sound case for regarding it as the outcome of a "folk religionization of Christianity" (Liu Ying-hua 2010, cf. also Reilly 2004: 6, 114, Wagner 1998: 133, for a contrasting view cf. Bohr 2004). What is important in our context is that the Taiping religion maintained a state of high tension with Chinese society throughout its existence. Iconoclastic in nature, it openly attacked all diffused and institutionalized forms of Chinese religions, including folk religion and notably ancestor worship as well as Buddhism and in particular Confucianism and even the institution of the Chinese emperor, who for the Taiping had become an 'idol' himself (Reilly 134-139). They no doubt drew confirmation of this attitude from the Bible, which - in a specific Chinese translation - they regarded as the supreme authoritative text (Reilly 2004: 133-134, Covell 1986: 152-156). On the other hand, its doctrines contained both popular religious and Confucian elements that appealed to people with a background in Chinese religions, in particular popular religion, as well as the millenarianism of folk lay groups (Bohr 2004: 393-394). To begin with, Hong regarded himself as part of a Heavenly family that included God, Jesus Christ, himself and their wives - a family, moreover, that functioned along the same principles as the Chinese family (Liu Ying-hua 2010: 100-101, Shih 1967: 4-15). Another important element in Taiping religion was a specific form of shamanism (wu 巫), in which a deity possesses a medium and speaks through them. The prophetic messages proclaimed not only by Hong himself, but also some of his lieutenants, had their origins in this belief and not in Old Testament prophecy. By the same token, Taiping exorcism borrowed from popular Daoism rather than from examples in the New Testament (Liu Ying-hua 2010: 101-103, Shih 1967: 320-328). Finally, the Taiping concept of sin echoed the Confucian belief that human nature is originally good rather than viewing sin as the original human condition that can only be escaped through Christ's redemption (Covell 1986: 162-166, Shih 1967: 181-183). Taiping Christianity thus spoke to Chinese religious concepts in ways that the missionaries could not and would not. Even so, it is doubtful whether those control measures put in place by the Taiping leadership were effective in guiding the religious behaviour of the rank and file, especially under the unstable conditions of civil war under which the Taiping operated (cf. Shih 1967: 23-29).

The emergence of an indigenous Christianity was the result of two trajectories that were interrelated, but also in conflict with one another: The first, which is well-covered in the literature, was the devolution of authority from the mission societies and the 'Western' 
missionaries to Chinese institutions such as the interdenominational and rather liberal Church of Christ in China (Zhonghua Jidujiaobui 中華基督教會), founded in 1927, and to an indigenous clergy. This process, often referred to as indigenization and carried out under the slogan of the “three self” (Bays 1995: 124 f.) - self-administration, self-support and self-propagation, phrases borrowed from early nineteenth-century 'Western' mission leaders (cf. Williams 2008 and 1990) , was, in most cases, tortuous and conflict-ridden. The reason was that the majority of missionaries were loath to part with the authority which they hitherto had been able to wield (Klein 2002, Chang 1999, Bickers 1996, Heininger 1982, Zha Shijie 1993: 32-35, but cf. Lodwick 1990, Hood 1986). It therefore comes as no surprise that tensions within the mission congregations peaked during the high tide of Chinese nationalism in the 1920s (Lian Xi 2004: 852-855). In the late nineteenth and early twentieth centuries, independent churches broke away from mission-led organizations, but these retained many denominational features (Xu Yihua 2004: 108) On the other hand, the 1920s also saw the development of indigenization theology, a liberal attempt to reconcile Christian beliefs with Chinese values (mostly those of Confucianism) at an academic theological level (So 1998, Chao 1992). After 1949, these divergent strands ended up under the umbrella of the Three Self Patriotic Movement (TSPM), a mass organization closely supervised by the Chinese Communist Party (CCP) (Xu Yihua 2004).

The other, which has more recently attracted scholarly attention, was the formation of indigenous Christian groups in the early twentieth century. The True Jesus Church, the Jesus Family, the Little Flock and others, including some independent figures, shared as their characteristic "a potent mix of evangelistic fervor, biblical literalism, charismatic ecstasies, and a fiery eschatology not infrequently tinged with nationalistic exuberance" (Lian Xi 2010: 2, cf. Bays 1995). It is quite plausible that, as Lian Xi has argued in his ground-breaking study, these groupings were the key players in transforming Christianity from the 'foreign religion' (yangjiao 洋

教) it had been in the nineteenth and early twentieth centuries into a popular mass religion probably numbering around 30 million adherents as of today (ibid.). ${ }^{8}$

How this was possible has yet to be ascertained, however. I find it difficult to take on board Lian's emphasis on the link between Christian and traditional Chinese millenarianism, which picks up the argument developed earlier by Daniel Bays on the 'sectarian' connections of Chinese Christianity (Lian Xi 2010: 235-240, cf. Bays 1983, 1985 and 1991). It is by no means certain that

8 For the importance of these 'number games' cf. Bays 2003: 185. For the mid-1990s, Währisch-Oblau (1996: 530) quotes estimates ranging from 8.5 million to more than 65 million Protestants, dismissing the latter as unsubstantiated. Fiedler (2010: 72) allows for a maximum of 40 million, but considers estimates of 25-30 million as most credible. Aikman (2003: 6-8) gives the decidedly most optimistic figures, estimating the combined Protestant-Catholic strength at more than 80 million as opposed to the official claims of only 21 million. 
the influence of popular religious lay groups permeated Chinese society in such a way as to account for the soaring of membership in Christian churches, even if we concede that it was certainly not limited to these groups' rather circumscribed membership. From the available evidence one might infer that the independent charismatic groups shifted the emphasis from the disciplinarian focus of the missionary congregations to a focus on spiritual experience. It must be noted, though, that those churches with a missionary background, most of which became selfgoverning in this period, experienced a similar shift, as Chinese church leaders strove both to improve the quality of Christians and to significantly increase their number (Sun Ensan 1931: 1). Independent lay evangelists were especially successful in increasing spirituality among church members (Gieß 1929, cf. Bays 1996: 313-315). Their activities no doubt helped to consolidate a sense of Christian identity as well as orthodoxy and orthopraxy. On the other hand, it contributed to the increasing perception of Christianity as a Chinese religion, thereby reducing tensions with society at large. Notwithstanding the shifting religious policies of the Nationalist and even more the Communist government after 1927 and 1949 respectively, the long-term consequences of the organizational and conceptual transformation of Christian congregations are probably still felt in the unprecedented and explosive growth of Chinese Christianity in the 'reform' era since 1978. The two most quoted factors behind this growth, faith healing and community orientation (Fiedler 2010, Währisch-Oblau 2001), work in different ways: While the former clearly is a bridge to popular religious concepts - important because the overwhelming majority of newcomers have their roots in popular religion -, the second builds on a reinforced sense of Christian identity.

Finally, it has to be noted that the expansion of Chinese Christianity has been accompanied by enormous diversification, allowing us to identify three major sectors: One the one hand, there is a 'bureaucratic' sector formed by the indigenization of mission churches and focused on the China Christian Council (CCC) and TSPM. Evangelical in orientation, it relies on its institutional structure, is led by professional theologians and pursues a top-down approach, although it lacks a fully established hierarchy. The "charismatic" sector mostly arose out of the indigenous groups discussed above; it is very much a grassroots movement under the leadership of laypeople. It is also overwhelmingly female; a proportion of 60-90\% of women (Währisch-Oblau 1996: 532-533) means a dramatic reversal of the male preponderance in the nineteenth and early twentieth centuries. Influenced by popular religion, the 'charismatic' sector is not limited to the so-called 'house churches', which distance themselves from the CCC, but also exists under the umbrella of

In context of this paragraph, the term 'charismatic' (in quotation marks) is not used to denote a charismatic form of Christianity (as above), but points to a grassroots version of Christianity that tends to be independent of guidance by professional and academic theologians. 
the latter organization, as for historical reasons the individual congregations enjoy a high degree of autonomy (Oblau 2001).

At the fringes of Protestant Christianity, there has emerged what Kristin Kupfer (2010: 29) has called 'Christian-inspired movements'. By this term she characterizes new religious groups that take some of their inspiration and concepts from Christianity, yet base their message of salvation and charismatic healing on the charismatic and authoritative powers of their leaders. Like the popular religious lay groups of old, they have developed a hierarchical structure by grouping their followers into different levels. The 'folk-religionization' of Christianity in these movements is much stronger than in the case of the Taiping movement, and their connection with mainstream Christian doctrines and practices is extremely loose. It is important to note in passing that both 'house churches' and 'Christian-inspired movements' are not part of the religious sector acknowledged as legitimate by the Communist party-state; as a consequence, both frequently become targets of persecution by the authorities.

What is more important in the context of this paper is the diversification of Christianity, which seems to have had two effects: On the one hand, it confirms the impression that Chinese Protestant Christianity in the post-missionary age has lowered tensions with society at large to a considerable degree. On the other hand, this process is by no means even, and in many sectors of Chinese Protestantism, the continued existence of a clergy that has in some ways inherited the role of the missionaries and seeks to maintain what it perceives to be higher standards of Christianity shows the continuation of tensions both within the church and between church and society after the demise of missionary leadership.

\section{Conclusion}

What can the 'supply-side model' contribute to our understanding of conversions to Christianity in the history of modern China? Conversely, how does the history of (Protestant) Christianity in modern China illuminate the 'supply-side model' of the religious economists and its explanation of religious change?

At a first glance, the above analysis bears out a number of central assumptions of the 'supplyside' model. To begin with, the history of Chinese Protestant Christianity, a nineteenth-century religious newcomer in China, suggests that religious change is influenced by the supply rather than by the demand side. In their initial approaches to the 'foreign teaching', Chinese converts viewed Christianity not as a new type of religion - in fact they lacked the very term and concept of 'religion' in its modern sense -, but rather as an option that added to those already available to 
them. There is nothing to indicate that without Christianity, these people would not have found within their established religious framework a solution for their personal crises which might have satisfied them. This becomes clear as we look at the motives for their conversion, which hardly indicate a notable shift in religious demand. In fact, as the missionaries found much to their chagrin, they pointed not to any spiritual needs or a hunger for redemption, but rather to the same aspects of human existence that the majority sought to deal with within the framework of folk religion or one of the established institutionalized religions.

Second, converts can be grouped into different niches according to their preferences, whether these may have been luck change, hope for economic betterment or a desire for protection. Although these motives did not differ from the mindset of the population writ large, the fact that only a fraction of the population flocked to the missionaries indicates that converts' demands must have been stronger than those of others to make them to cross the threshold to Christianity. There was a lot to deter them from becoming Christian: an alien and often repulsive imagery and terminology and - as people began to develop an understanding of Christianity, however distorted it may have been - the pressure from their non-Christian neighbours and kin. These tensions with the converts' immediate social environment (which the missionaries may have exaggerated in their reports) must be weighed against those cases where social networks did facilitate the spread of Christianity. The factors pulling them to the foreign religion must have been strong indeed, be they disappointment at the established forms of religion, economic hardship (which was not necessarily identical with poverty) or lack of power. The paradox of Chinese conversions to Christianity was that on the one hand, as they took place amidst contending influences, converts must have been very clear that they were making a choice, while on the other hand they were ignorant of the standards by which they were measured in their new religion. For the majority of neophytes, the term 'seekers of truth' actually was a misnomer.

Finally, the first Chinese Protestant churches originated under the leadership of missionaries and as small, 'sect'-like groups that closely monitored the activities of their members and sanctioned transgressions. This resulted in high tensions between the Chinese Christian congregations and the rest of society, although these tensions were eased somewhat in the early twentieth century as the missionary era drew to a close. At any rate, both the evidence on the ephemeral Taiping movement and on indigenous Christian churches would confirm that groups allowing for a greater cultural continuity were more dynamic and successful in attracting adherents. However, this is not necessarily true of the contemporary 'Christian-inspired' movements, some of which remain rather small, while others expand (Kupfer 2010: 237). ${ }^{10}$

10 One would have to determine for each of these groups to what extent state persecution plays a role in their successes or failures, but this clearly surpasses the limitations of this article. 
At closer inspection, questions remain. For one thing, the concept of religious firms - which appears rather underdetermined in Acts of Faith as compared to earlier versions of the religious economy model (cf. Iannaccone 1998: 1482-1485) - would suggest that these are organizations with a propensity for maximal growth. This does not dovetail nicely with one of the central tensions in early Chinese Protestant Christianity: the contradiction between dynamic advertising on the one hand and strictness on the other. In theory, missionaries were working towards the Christianization of all of China, and there is no doubt that they spent a lot of energy on advertising Christianity. On the other hand, they conceived of their congregations as 'strict', closely monitored organizations and therefore were very restrictive in admitting new members. Independent missionaries such as Gützlaff, who aimed at the conversion of the largest possible number of Chinese in the shortest possible time, were in a minority, while the majority of missionaries prioritized 'quality' over 'quantity'. This raises the question of whether the religious economy model has adequately addressed the standards of religious expansion. This question becomes even more pressing when, leaving Christianity aside for a moment, we address those sectors of 'diffused' Chinese religion that the overwhelming majority of Chinese Christians came from. Their membership was defined by kinship or settlement and therefore stable by definition, and while they clearly did not proselytize (quite the contrary), there also was no easy way to opt out of them, as many Christian converts would experience to their detriment.

Another question concerns the problem of cultural continuity. According to the 'supply-side model', religious organizations are more successful in attracting followers to the extent that they allow for a cultural continuity. It is one of the strange paradoxes of the history of Christian missions in China, however, that while the majority of the population stayed aloof from Christianity in the nineteenth and early twentieth centuries because of its alien character, most if not all converts seem to have found it easy to interpret their new faith in terms of concepts inherited from popular religion. This phenomenon is not really covered by Stark's notion of 'cultural continuity' as explained above (Stark 2003: 261). In particular, Stark fails to address the cultural baggage of converts as an interpretive framework with which to address their new religion, which is precisely what defined Chinese conversions to Christianity. Thus while Stark's concept is able to account for the low membership figures of Protestant congregations up to 1949 - because Christianity was so culturally different from Chinese traditions - , it fails to explain the character of the conversion process itself, which was so strongly determined by Chinese popular religion.

As a consequence of the lingering influence of popular religion, perhaps the most fundamental tension running through the missionary-led Christian congregations was that between the missionaries' expectations of conversion as a spiritual rebirth and the predispositions 
of Chinese Christians as outlined above. To explain this as a low degree of religious commitment - understood as the failure to meet the obligations of the Christian God as defined by the missionaries - is to miss the point. The concepts of religious organizations are not fixed; they may shift and they allow for some degree of flexibility, as the missionaries' willingness to compromise on some issues clearly shows. On the other hand, it might be argued that the lowering of tensions was the result and not a precondition of the post-1978 expansion of Protestant Christianity. As a consequence of its rapid spread at the grassroots level, the Chinese 'bureaucratic sector' - which, as we have seen, to some extent has inherited the missionary tradition, in particular when it comes to the 'quality' of Christians - found it even more difficult to control the religious knowledge, beliefs and practices of ordinary Christians. The role of independent churches in this process (and especially its attitude towards church discipline) needs to be better understood, but the available evidence seems to suggest that while they may have laid the groundwork for Protestantism to be accepted as a 'Chinese' religion, prior to 1949 (or even 1978), their growth was not remarkably faster than that of the mission-led churches.

One of the fundamental problems of the 'supply-side model' is its disinterest in religious concepts. ${ }^{11}$ In fact, not only do emic perspectives hardly play any role, but it also seems that empirical evidence is occasionally bent to suit the theoretical framework rather than vice versa. There is, for example, no instrument to deal with ancestor worship - religion is an exchange relationship with god(s), while every handling of supernatural forces without reference to god(s) counts as magic. As ancestor worship clearly is not magic, is it legitimate to subsume ancestors under the category of 'good gods' (Stark and Finke 2000: 97)? To answer in the affirmative would gloss over the enormous differences between the two categories, which are important for the understanding of Christianity in China, both because of the way ancestor worship inhibited conversion and because of the missionary responses to the phenomenon.

In fact, although the 'supply-side model' further develops the religious economy approach in that it takes social and cultural factors into account, it still lacks an adequate understanding of the cultural implications of religious change. For example, advocates of the 'supply-side model' posit unequivocal terms of religious exchange, more or less explicitly assuming a hierarchy of rewards, with life after death at the top because it is the most costly, involving an exclusive relationship with one god and not to be gained in the here and now. If this logic were so clear to religious actors as religious economists seem to assume, one wonders how people might not see the advantages. After all, this is not like buying a luxury item one cannot afford, it is about shunning costs that it would be in one's power to bear. The problem is that, as even some economists and

11 Bruce (2000: 42) talks about the supply-siders' lack of "reference to differences in theology or ecclesiology" - an understanding that must be broadened for the purpose of this article. 
sociologists now argue, the value of goods is not naturally given, but an interpretive construct (Jagd 2007: 76; cf. Dosse 1998: 258-261, Storper and Salais 1997: 19). It is therefore impossible to "begin with an actor free of all such [cultural] constraints" and see "how culture is discovered and accumulated" because religious actors are always cultural beings. In the nineteenth and early twentieth centuries, Christianity was not an option for the overwhelming majority of the Chinese because they were content with what benefits they received from their religious activity. Missionaries found it difficult to convince them of the need for salvation because this idea had no place within their cultural framework. Conversions to Christianity took place because the missionaries were offering their religion (the supply side) and because in a recurring pattern (the niche), people had demands that the traditional religious options seemingly could not fulfil (the demand side) - but these demands were articulated against the converts' own cultural background.

Finally, the 'supply-side model' treats religion more or less as a closed system. Religious change is attributed to shifts in a 'religious economy' which consists solely of adherents, organizations and the "religious culture" offered by the latter (Stark and Finke 2000: 193). However, the model ignores that religions are linked to other aspects of social existence, such as politics, culture and the economy, which influence the dynamics of religions and in particular religious change. Economic incentives did play a certain role in conversions to Christianity in late Imperial and early Republican times, and even more so the ability of missionaries to act as power brokers and manipulate local power structures - to the extent that the missionaries themselves ended up being manipulated. On the other hand, the shift from an overwhelmingly male to an even more overwhelmingly female Protestantism must be attributed to the dramatic change in the status of women in Chinese society between the late nineteenth and late twentieth centuries. In this sense, niches were formed not only through (shifting) religious preferences, but also through sociocultural transformations.

Given the insufficiencies of the religious economy model, there is no doubt a need to go 'beyond the market' in explaining religious change in modern China. Religious supply, demand and competition should be seen as forces working on the dynamics of religious traditions and interactions between religions, but they should not be addressed as 'naturally given' in the tradition of neoclassical economics. Rather, they are cultural constructs, the result of interpretive frameworks that govern the shift from one religion to another. Thus, religious change is governed by cultural interpretations, as well as social transformations and political power shifts. In a critique and expansion of Bourdieuan theory, Goossaert and Palmer (2011: 9-11) have identified the 'religious field' in China as a not only religious, but also political project that almost by definition - remained incomplete, both inscribing itself into a wider religious landscape 
and relating to other 'fields' in society. Christian missionaries has played an important part in the emergence this project in the nineteenth century, but the result of their activities has been mixed. On the one hand, Christian attempts to denigrate all non-Christian religions as superstitions have left traces in the Chinese intellectual and political realm; on the other - as I have shown in this paper - missionaries have been unable to prevent 'superstitions' from working their way into Christianity.

Coming full circle, I will finally address the question whether Christianity was indeed more competitive on the Chinese market. The religious economists' claims that exclusive religions always win is overly optimistic because of the historical examples they cite, Christianity and Islam have emerged as dominant religions because they managed to ally - or to be identical - with the highest-level political power. In view of the above discussion, one might say that they made possible the construction of a 'religious field'. From what we know about the present condition of China, it is far from likely that Christianity will be an attractive basis on which to build a political project for the Chinese Communist Party, which holds the reins of political power in Beijing and will continue to do so. Seen in this light, David Aikman's (2003: 285-287) prediction that around 20-30 per cent of the Chinese population will become Christians within the next three decades, leading to a dominance of the Christian world view in China's political and cultural establishment and possibly to a global burden-sharing between the People's Republic and the United States, appears to be a rather self-serving fantasy. Chinese Christianity is far remote from the centre of power and so far has largely abstained from political activism (Lian Xi 2010: 242). Moreover, even a success of a Christianity, large parts of which have "shown a greater tendency to absorb, and be absorbed by, popular religion rather than replace it" (ibid.), would not mean necessary a better understanding on a world scale. The cultural dynamics of Christianity in China and the West might work against as well as towards global harmony.

\section{Acknowledgements}

This article has been long in coming. Much of the initial research (especially with regard to the theoretical framework) was conducted during my research fellowship at the College of Cultural Studies, University of Constance, Germany. I wish to thank the College for its intellectually stimulating atmosphere and generous support. Thanks also go to Hubert Seiwert, Christian Meyer and two anonymous reviewers for providing valuable comments on this and earlier versions of my text. 


\section{Bibliography}

Aikman, David. 2003. Jesus in Beijing. How Christianity Is Transforming China and Changing the Global Balance of Power, Washington, DC: Regnery Publishing.

Altena, Thorsten. 2003. "Ein Häuflein Christen mitten in der Heidenwelt des dunklen Erdteils". Zum Selbst- und Fremdverständnis protestantischer Missionare im kolonialen Afrika. Münster: Waxmann.

Austin, Alvyn J. 2007. China's Millions. The China Inland Mission and Late Qing Society, 18321905. Grand Rapids, MI: Eerdmans.

Base Shenghui Guitiao 巴色聖會規條. 1874. Mission 21, Basel Mission Archives A III b 16.

Bays, Daniel H. 1983. Christianity and the Chinese sectarian tradition. Ch'ing-shih Wen-t'i 4: 3355.

Bays, Daniel H. 1985. Christianity and Chinese Sects: Religious Tracts in the Late Nineteenth Century. In Christianity in China. Early Protestant Missionary Writings, ed. Suzanne Wilson Barnett, John King Fairbank. Cambridge, MA: Harvard University Press, 121-134.

Bays, Daniel H. 1991. Chinese Popular Religion and Christianity before and after the 1949 Revolution: a Retrospective View. Fides et Historia 23: 69-77.

Bays, Daniel H. 1996. The Growth of Independent Christianity in China. In Christianity in China. From the Eighteenth Century to the Present, ed. Daniel H. Bays. Stanford, CA: Stanford University Press, 307-316.

Bays, Daniel H. 2003. Chinese Protestant Christianity Today. In Religion in China Today, ed. Daniel L. Overmyer. Cambridge : Cambridge University Press, 182-198.

Berling, Judith. 1980. The Syncretic Religion of Lin Chao-en. New York: Columbia University Press.

Bianco, Lucien. 2005. Jacqueries et révolution dans la Chine du XXe siècle. Paris: Éditions de la Martinière.

Bickers, Robert A. 1996. "To Serve and Not To Rule": British Protestant Missionaries and Chinese Nationalism, 1928-1931. In Missionary Encounters. Sources and Issues, ed. Rosemary Seton, Robert Bickers. Richmond: Curzon Press, 211-238.

Bohr, P. Richard. 2004. The Taipings in Chinese Sectarian Perspective. In Heterodoxy in Late Imperial China, ed. Kwang-ching Liu, Richard Shek. Honolulu, HI: University of Hawai'i Press, 393-430.

Brockey, Liam Matthew. 2007. Journey to the East. The Jesuit Mission to China, 1579-1724. Cambridge, MA: Harvard University Press. 
Brook, Timothy. 1993. Rethinking Syncretism: The Unity of the Three Teachings and their Joint Worship in Late-Imperial China. Journal of Chinese Religions 21: 13-44.

Bruce, Steve. 2000. The Supply-Side Model of Religion: The Nordic and Baltic States. Journal for the Scientific Study of Religion 39: 32-46.

Bruce, Steve. 2008. The Social Limits on Religious Markets. In Salvation Goods and Religious Markets, ed. Jörg Stolz. Bern: Lang, 81-100.

Bruun, Ole. 2003. Fengshui in China. Geomantic Divination Between State Orthodoxy and Popular Religion. Copenhagen: NIAS Press.

Bryant, Joseph M. 2000. Cost-Benefit Accounting and the Piety Business: Is Homo Religiosus, at Bottom, a Homo Economicus?. Method \& Theory in the Study of Religion 12: 520-548.

Chang, Ning J. 1999. Tension Within the Church: British Missionaries in Wuhan, 1913-28. Modern Asian Studies 33: 421-444.

Chao, Jonathan T'ien-en. 1992. Toward a Chinese Christianity. A Protestant Response to the Anti-Imperialist Movement. Republican China 17: 95-109.

Chau, Adam Yuet. 2006. Miraculous Response. Doing Popular Religion in Contemporary China. Stanford, CA: Stanford University Press.

Chen Jiasheng 陳家勝. 1997. Longchuan xian Tongqu zhen Tianxin tun zongzu yu minsu 龍川 縣通奮鎮田心屯宗族與民俗 [Customs and Lineages of Xindun [sic!] Village, Longchuan]. In Meizhou Heyuan diqu de cunluo wenhua 梅州河源地區的村落文化 [Village Religion and Culture in Northeastern Guangdong], ed. Fang Xuejia 房學嘉. N. p.: International Hakka Studies Association, Overseas Chinese Archives and Ecole Française d'Extrême-Orient, 427441.

Chen, May Ming-chun. 1998. Familism and the Protestant Expansion in China. Ching Feng 41: 171-197.

Cheung, David. 2004. Christianity in Modern China. The Making of the First Native Protestant Church. Leiden: Brill.

Cohen, Myron. 1992. Religion in a State Society: China. In Asia. Case Studies in the Social Sciences, ed. Myron Cohen. Armonk, NY: Sharpe, 17-31.

Cohen, Paul A. 1978. Christian Missions and Their Impact to 1900. In The Cambridge History of China. Vol. 10: Late Ch’ing, 1860-1911, Part I, ed. John K. Fairbank. Cambridge: Cambridge University Press, 543-590.

Corbett, Hunter. 1890. Church Discipline. In Records of the General Conference of the Protestant Missionaries of China Held at Shanghai, May 7-20, 1890. Shanghai: American Presbyterian Mission Press. 
Covell, Ralph R. 1986. Confucius, the Buddha, and Christ. A History of the Gospel in Chinese. Maryknoll: Orbis Books.

Dosse, François. 1998. Empires of Meaning. The Humanization of the Social Sciences. Minneapolis, MN: University of Minnesota Press.

Duara, Prasenjit. 1991 Knowledge and Power in the Discourse of Modernity: The Campaigns against Popular Religion in Early Twentieth-Century China. Journal of Asian Studies 50: 6783.

Dunch, Ryan. 2001. Fuzhou Protestants and the Making of a Modern China 1857-1927. New Haven, CT: Yale University Press.

Durkheim, Emile. 1915. The Elementary Forms of the Religious Life. London: Allen \& Unwin.

Eber, Irene. 1999. The Interminable Term Question. In Bible in China. The Literary and Intellectual Impact, ed. Irene Eber, Sze-Kar Wan, Knut Walf. Sankt Augustin: Institute Monumenta Serica, 135-161.

Edgerton-Tarpley, Catherine. 2009. "Governance with Government”. Non-State Responses to the North China Famine of 1876-1879. Berliner China-Hefte 35: 33-47.

Esherick, Joseph W. 1987. The Origins of the Boxer Uprising. Berkeley, CA: University of California Press.

Fan Wei. 1992. Village Fengshui Principles. In: Chinese Landscapes. The Village as Place, ed. Ronald G. Knapp. Honolulu, HI: University of Hawaii Press, 35-45.

Feuerwerker, Albert. 1976. The Foreign Establishment in China in the Twentieth Century. Ann Arbor, MI: Center for Chinese Studies, University of Michigan.

Fiedler, Katrin. 2010. China’s “Christianity Fever” Revisited: Towards a Community-Oriented Reading of Christian Conversions in China. Journal of Current Chinese Affairs 39.4: 71-109.

Finke, Roger. 1998. Religious Choice and Competition. American Sociological Review 63: $761-$ 766.

Finke, Roger, Laurence Iannaccone. 1993. Supply-Side Explanations for Religious Change. Annals of the American Academy for Political Science 527: 27-39.

Gaustad, Blaine. 2000. Prophets and Pretenders: Inter-Sect Competition in Qianlong China. Late Imperial China 21.1: 1-40.

Gentz, Joachim. 2006. Die drei Lehren (sanjiao) Chinas in Konflikt und Harmonie. Figuren und Strategien einer Debatte. In Religionen Nebeneinander. Modelle religiöser Vielfalt in Ost- und Südostasien, ed. Edith Franke, Michael Pye. Berlin: LIT, 17-40.

Gernet, Jacques. 1985. China and the Christian Impact: A Conflict of Cultures. Cambridge: Cambridge University Press. 
Gieß, Heinrich. 1929. Freiwillige Laienprediger in China. Der evangelische Heidenbote 102: 124125.

Goossaert, Vincent. 2006. 1898: The Beginning of End for Chinese Religion? Journal of Asian Studies 65: 307-336.

Goossaert, Vincent. 2007. The Taoists of Peking, 1800-1949. A Social History of Urban Clerics. Cambridge, MA: Harvard University Press.

Goossaert, Vincent, David Palmer. 2011. The Religious Question in Modern China. Chicago, IL: Chicago University Press.

Greeley, Andrew M. 1998. Pie in the Sky While You're Alive: Americans' Belief in Life after Death and Supply-Side Religion, http://www.agreeley.com/articles/piesky.html\#N 1.

Hayes, James. 1985. "Specialists and Written Materials in the Village World". In Popular Culture in Late Imperial China, ed. David Johnson, Andrew J. Nathan and Evelyn S. Rawski. Berkeley, CA, Los Angeles and London: University of California Press, 75-111.

Heininger, Janet E. 1982. Private Positions Versus Public Policy: Chinese Devolution and the American Experience in East Asia. Diplomatic History 6: 287-302.

Hood, George. 1986. Mission Accomplished? The English Presbyterian Mission in Lingtung, South China. Frankfurt: Lang 1986.

Iannaccone, Laurence R. 1994. Why Strict Churches are Strong. American Journal of Sociology 99: 1180-1211.

Iannaccone, Laurence R. 1998. Introduction to the Economics of Religion. Journal of Economic Literature 36: 1465-1495.

Jagd, Søren. 2007. Economics of Convention and New Economic Sociology. Mutual Inspiration and Dialogue. Current Sociology 55: 75-91.

Jagodzinski, Wolfgang, Andrew Greely. no date. The Demand for Religion. Hard Core Atheism and "Supply Side" Theory, http://www.agreeley.com/articles/hardcore.html.

Jenkins, Paul. 1978. Towards a Definition of the Pietism of Wurtemberg as a Missionary Movement. Paper presented at the African Studies Association of the United Kingdom Conference 'Whites in Africa - Whites as Missionaries'.

Jordan, David K. 1972. Gods, Ghosts, and Ancestors. The Folk Religion of a Taiwanese Village. Berkeley, CA: University of California Press.

Jordan, David K. 1993. The Glyphomancy Factor: Observations on Chinese Conversion. In Conversion to Christianity. Historical and Anthropological Perspectives on a Great Transformation, ed. Robert W. Hefner. Berkeley, CA: University of California Press, 285-303. Jörgensen, Helle. 2001. Funktionalisierung der Mission durch chinesische Christen: Die protestantische Rheinische Missionsgesellschaft im Kreis Dongguan in der Provinz 
Guangdong. In Deutsch-chinesische Beziehungen im 19. Jahrhundert. Mission und Wirtschaft in interkultureller Perspektive, ed. Mechthild Leutner, Klaus Mühlhahn. Münster: LIT, 219260.

Klein, Thoralf. 2002. Die Basler Mission in der Provinz Guangdong, 1859-1931. Akkulturationsprozesse und kulturelle Grenzziehungen zwischen Missionaren, chinesischen Christen und lokaler Gesellschaft. Munich: Iudicium.

Klein, Thoralf. 2004. The Basel Mission as a Transcultural Organization: Photographs of Chinese Christians and the Problem of Agency. In Getting Pictures Right. Context and Interpretation, ed. Michael Albrecht, Veit Arlt, Barbara Müller and Jürg Schneider. Cologne: Köppe 2004, 3956.

Klein, Thoralf. 2005. Protestant Missionaries and Communist Cadres as Local Power Brokers in Rural South China, 1890-1930 - A Comparison. In Mission und Macht im Wandel politischer Orientierungen. Europäische Missionsgesellschaften und ihre Tätigkeit in Afrika und Asien zwischen 1800 und 1945 in politischen Spannungsfeldern, ed. Ulrich van der Heyden, Holger Stoecker. Stuttgart: Steiner, 285-305.

Kuhn, Philip A. 1977. Origins of the Taiping Vision: Cross-Cultural Dimensions of a Chinese Rebellion. Comparative Studies in Society and History 19: 350-366.

Lagerwey, John. 2000. The Structure and Dynamics of Chinese Rural Society. In: Lishi yu shehui jingji. Di-si jie guoji Kejiaxue yantaohui lunwenji 歷史與社會經濟。第四屆國際客家學研 討會論文集 [History and Socio-economy. Proceedings of the Fourth International Conference on Hakkaology], ed. Xu Zhengguang 徐正光. Taipei: Institute of Ethnology, Academia Sinica, 1-43.

Lamley, Harry J. 1977. Hsieh-tou: The Pathology of Violence in Southeastern China. Ch'ing Shih Wen-t'i 3: 1-39.

Lamley, Harry J. 1990. Lineage Feuding in Southern Fujian and Eastern Guangdong under Qing Rule. Violence in China. Essays in Culture and Counterculture, ed. Jonathan N. Lipman and Stevan Harrell. Albany: State University of New York Press, 27-64.

Lang, Graeme, Selina Ching Chan, Lars Ragvald. 2005. Temples and the Religious Economy. Interdisciplinary Journal of Research on Religion 1:1-27.

Latourette, Kenneth Scott. 1929. A History of Christian Missions in China. New York: Macmillan.

Lechler, Rudolf. 1878. On the Relation of Protestant Missions to Education. In Records of the General Conference of the Protestant Missionaries of China Held at Shanghai, May 10-24, 1877. Shanghai: Presbyterian Mission Press, 160-171. 
Lechler, Rudolf. 1890. I. Method of Dealing with Inquirers. - II. Conditions of Admission to Church Fellowship - III. Best Methods of Discipline. In Records of the General Conference of the Protestant Missionaries of China Held at Shanghai, May 7-20, 1890. Shanghai: American Presbyterian Mission Press.

Lee, Joseph Tse-hei. 2003. The Bible and the Gun. Christianity in South China, 1860-1900.New York: Routledge.

Lee, Joseph Tse-Hei. 2009. Disaster Management and Christian Church Networks in Early Twentieth-Century Chaozhou, South China. Berliner China-Hefte 35: 64-79.

Li Shiyuan 李湜源. 1995. Chong lun Zhongwen 'Shengjing' zhong “zui” zi de fanyi wenti 重論 中文“聖經’中“罪”字的翻譯問題 [A reexamination of the translation problems concerning the character "zui" in the Chinese Bible]. In: Dao yu xin. Huaxia wenhua yu Jidu wenhua de xiangyu [Dao and Belief. The Encounter Between Chinese Culture and Christian Culture], ed. Liu Xiaofeng 劉小楓. Hong Kong: Sanlian Shuju 1995, 637-645.

Li, Thomas Shiyu, Susan Naquin. 1988. The Baoming Temple: Religion and the Throne in Ming and Qing China. Harvard Journal of Asiatic Studies 48: 131-188.

Lian Xi. 2004. The Search for Christianity in Republican China (1912-1949). Modern Asian Studies 38, 851-898. DOI: 10.1017/S0026749X04001283.

Lian Xi. 2010. Redeemed by Fire. The Rise of Popular Christianity in Modern China. New Haven, CT: Yale University Press.

Litzinger, Albert. 1996. Rural Religion and Village Organization in North China: The Catholic Challenge in the Late Nineteenth Century. In Christianity in China. From the Eighteenth Century to the Present, ed. Daniel H. Bays. Stanford, CA: Stanford University Press, 41-52.

Liu, Kwang-ching, ed. 1990. Orthodoxy in Late Imperial China. Berkeley, CA: University of California Press.

Liu, Kwang-ching, Richard Shek, ed. 2004. Heterodoxy in Late Imperial China. Honolulu, HI: University of Hawai'i Press.

Liu Ying-hua. 2010. The Folk-religionization of Christianity in China - Hong Xiuquan's Yuandao jueshi xun and the Taiping Rebellion, in: Shizijia qian de sisuo - wenben jiedu yu Shengjing quanshi 十字架前的思索 - 文本解讀與聖經詮釋 [Pondering before the Cross - Reading Texts and Interpreting the Gospel] ed. Wang Chengmian 王成勉. Taipei: Liming Wenhua, $77-106$ 
Lodwick, Kathleen L. 1990. Chinese Leadership in the Presbyterian Church in Hainan: 18851919. In Jidujiao yu Zhongguo bensehua 基督教與中國本色化[Christianity and Chinese Indigenization], ed. Lin Zhiping 林治平. Taipei: Yuzhouguang, 548-568.

Lu Yunfeng. 2005. Entrepreneurial Logics and the Evolution of Falun Gong. Journal for the Scientific Study of Religion 44:173-185. DOI: 0.1111/j.1468-5906.2005.00274.x.

Lu Yunfeng. 2008. Chaoyue Jidu zongjiao shehuixue - jian lun zongiiao shichang lunli zai Huaren shehui shiyongxing wenti 超越基督宗教社會學 -兼論宗教時常論理在華人社會實用性 問題 [Beyond a Christian Sociology of Religion. A Discussion of the Applicability of the Religious Market Theory to Chinese Societies]. Shehuixue yanjiu 社會學研究 2008/5, http://www.sopku.com/document/zhongxinyanjiuwenxian/ yunfeng1/.

Luo Zhufeng. 1991. Religion under Socialism in China. Armonk, NY: Sharpe.

Lutz, Jessie G. 2008. Opening China. Karl F.A. Gützlaff and Sino-Western Relations, 1827-1852. Grand Rapids, MI: Eerdmans.

Lutz, Jessie Gregory, Rolland Ray Lutz. 1995. The Invisible China Missionaries: The Basel Mission's Chinese Evangelists, 1847-1866. Mission Studies 12: 204-227.

Lutz, Jessie Gregory, Rolland Ray Lutz. 1998. Hakka Chinese Confront Protestant Christianity, 1850-1900. With the Autobiographies of Eight Hakka Christians, and Commentary. Armonk, NY: Sharpe.

McCleary, Rachel M., Leonard W.J. van der Kuijp. 2010. The Market Approach to the Rise of the Geluk School, 1419-1642. Journal of Asian Studies 69: 149-180. DOI:10.1017/S0021911809991574.

Minden, Karen. 1994. Bamboo Stone. The Evolution of a Chinese Medical Elite. Toronto: University of Toronto Press.

Najarian, Nishan J. 1982. Religious Conversion in Nineteenth-Century China. Face-to-Face Interaction Between Western Missionaries and the Chinese. In: Social Interaction in Chinese Society, ed. Sidney L. Greenblatt, Richard L. Wilson and Amy Auerbacher Wilson. N.p.: Praeger, 67-111.

Nedostup, Rebecca A. 2009. Superstitious Regimes. Religion and the Politics of Chinese Modernity. Cambridge, MA: Harvard University Press.

Noyes, H.V. 1890. How Far Should Christians Be Required to Abandon Native Customs? In Records of the General Conference of the Protestant Missionaries of China Held at Shanghai, May 7-20, 1890. Shanghai: American Presbyterian Mission Press, 609-619. 
Oblau, Gotthard. 2001. Pentecostal by default? Reflections on Contemporary Christianity in China, http://www.doam.org/archiv/textea/china/china gotthardoblau pentecostalbydefault2001.p df.

Ohlinger, F. 1890. How Far Should Christians Be Required to Abandon Native Customs. In Records of the General Conference of the Protestant Missionaries of China Held at Shanghai, May 7-20, 1890. Shanghai: American Presbyterian Mission Press, 603-609.

Osterhammel, Jürgen. 1997. Shanghai, 30. Mai 1925. Die chinesische Revolution. München: Deutscher Taschenbuch Verlag.

Overmyer, Daniel L. 1984. Attitudes Toward the Ruler and State in Chinese Popular Religious Literature: Sixteenth and Seventeenth Century Pao-chüan. Harvard Journal of Asiatic Studies 44: 347-379.

Overmyer, Daniel L. 1999. Precious Volumes. An Introduction to Chinese Sectarian Scriptures from the Sixteenth to the Seventeenth Centuries. Cambridge, MA: Harvard University Asia Center.

Paper, Jordan D. 1987. The Ritual Core of Chinese Religion. Religious Studies and Theology 7, $19-35$.

Paper, Jordan D. 1995. The Spirits are Drunk. Comparative Approaches to Chinese Religion. Albany, NY: State University of New York Press.

Potter, Pitman B. 2003. Belief in Control: Regulation of Religion in China. In Religion in China Today, ed. Daniel L. Overmyer. Cambridge: Cambridge University Press, 11-31.

Records of the General Conference of the Protestant Missionaries of China Held at Shanghai, May 10-24, 1877. 1878. Shanghai: Presbyterian Mission Press.

Records of the General Conference of the Protestant Missionaries of China Held at Shanghai, May 7-20, 1890. 1890. Shanghai: American Presbyterian Mission Press.

Reilly, Thomas H. 2004. The Taiping Heavenly Kingdom. Rebellion and the Blasphemy of Empire. Seattle, WA: University of Washington Press.

Rosenbaum, Arthur Lewis. 2006. Christianity, Academics, and National Salvation in China: Yenching University, 1924-1949. Journal of American-East Asian Relations 13, 25-54.

Seiwert, Hubert. 2003. Popular Religious Movements and Heterodox Sects in Chinese History. Leiden: Brill.

Shih, Vincent. 1967. The Taiping Ideology. Its Sources, Interpretations, and Influences. Seattle, WA: University of Washington Press.

Smith, Arthur H. 1899. Village Life in China. A Study in Sociology. New York: Revell. 
So, Eric S.O. 1996. Timothy Tingfeng Lew and the Indigenization of the Church in China. Ching Feng 39, 237-253.

Standaert, Nicolas. 2001. Christianity in late Ming and early Qing China as a case of cultural transmission. In China and Christianity. Burdened past, Hopeful Future, ed. by Stephen Uhalley and Wu Xiaoxin. Armonk, NY: Sharpe, 81-116.

Stanley, Brian. 1990. The Bible and the Flag. Protestant missions and British imperialism in the nineteenth and twentieth centuries. Leicester: Apollos.

Stark, Rodney. 1996. The Rise of Christianity. A Sociologist Reconsiders History. Princeton, NJ: Princeton University Press.

Stark, Rodney. 2003. Why Religious Movements Succeed or Fail: A Revised General Model. In Cults and New Religious Movements. A Reader, ed. by Lorne L. Dawson. Oxford: Blackwell, 259-270.

Stark, Rodney, William Sims Bainbridge. 1979. Cult Formation: Three Compatible Models. Sociological Analysis 40: 283-295.

Stark, Rodney, William Sims Bainbridge. 1985. The Future of Religion. Secularization, Revival and Cult Formation. Berkeley, CA: University of California Press.

Stark, Rodney, Roger Finke. 2000. Acts of Faith. Explaining the Human Side of Religion. Berkeley, CA: University of California Press.

Stark, Rodney, Laurence Iannacone. 1994. A Supply-Side Reinterpretation of the "Secularization" of Europe. Journal for the Scientific Study of Religion 33: 230-252.

Stauffer, Milton T. 1922. The Christian Occupation of China. A General Survey of the Numerical Strength and Geographical Distribution of the Christian Forces in China Made by the Special Committee on Survey and Occupation, China Continuation Committee, 1918-1921. Shanghai: China Continuation Committee.

Stenz, Georg. 1906. Der Bauer in Schantung. Anthropos 1: 435-452, 838-863.

Stolz, Jörg. 2008. Salvation Goods and Religious Markets: Integrating Rational Choice and Weberian Perspectives. In Salvation Goods and Religious Markets, ed. Jörg Stolz. Bern: Lang, $51-80$.

Storper, Michael, Robert Salais. 1997. Worlds of Production. The Action Frameworks of the Economy. Cambridge, MA: Harvard University Press.

Streit, Karl. 1906. Statistische Notizen zum katholischen Missionsatlas. Steyl: Verlag der Missionsdruckerei.

Su Jing 蘇精. 2005. Zhongguo, kai men! Malisun ji xiangguan renwu yanjiu 中國, 開門！馬禮 遜及相關研究 [Open up, China! Studies on Robert Morrison and his Circle]. Hong Kong: Jidujiao Zhongguo Zongjiao Wenhua Yanjiushe. 
Sun Ensan 孫恩三. 1931. Wu nian yundong zhi faren yu jincheng 五年運動之發軔與進程

[The Beginning and Progress of the Five Year Movement]. Zhonghua Jidu Jiaohui nianjian 11: $1-13$.

Tawney, Richard Henry. 1932. Land and Labour in China. New York: Harcourt, Brace \& Co. ter Haar, Barend J. 1992. The White Lotus Teachings in Chinese Religious History. Leiden: Brill. Tiedemann, R.G. 1996. Christian Missions in Shandong in the Context of China's National and Revolutionary Development. In Missionsgeschichte - Kirchengeschichte - Weltgeschichte, ed. Ulrich van der Heyden, Heike Liebau. Stuttgart: Steiner, 387-404.

Tiedemann, R.G. 1998. Boxers, Christians and the Culture of Violence in North China. Journal of Peasant Studies 25/4: 150-160.

Tiedemann, R.G. 2001. Conversion Patterns in North China. Sociological Profiles of Chinese Christians, 1860-1912. In Authentic Chinese Christianity. Preludes to Its Development, ed. Ku Wei-ying, Koen de Ridder. Leuven: Leuven University Press, 107-133.

Voas, David, Daniel V. A. Olson, Alasdair Crockett. 2002. Religious Pluralism and Participation: Why Previous Research is Wrong. American Sociological Review 67: 212-230.

Währisch-Oblau, Claudia. 1996. Die Gemeinden im Bereich des Chinesischen Christenrates. Skizze einer Bewegung auf dem Weg zur verfaßten Kirche. In „Fallbeispiel“ China. Ökumenische Beiträge zu Religion, Theologie und Kirche im chinesischen Kontext, ed. Roman Malek. Nettetal: Steyler Verlag, 529-551.

Währisch-Oblau, Claudia. 2001. God Can Make Us Healthy through and through: On Prayers for the Sick and the Interpretation of Healing Experiences in Christian Churches in China and African Immigrant Congregations in Germany. International Review of Mission 90: 87-102.

Wagner, Rudolf G. 1998. Understanding Taiping Christian China. Analogy, Interest, and Policy. In "Christen und Gewürze". Konfrontation und Interaktion kolonialer und indigener Christentumsvarianten, ed. Klaus Koschorke. Göttingen: Vandenhoeck \& Ruprecht, 132-157. Wang Dong. 2007. Managing God's Higher Education. U.S.-China Cultural Encounter and Canton Christian College (Lingnan University), 1888-1952. Lanham, MD: Rowman \& Littlefield.

Wang Xiaoming 王曉明. 2003. “Zhonghua Suwei’ai Gongheguo Xianfa Dagang” zhong de zongiiao zhengce “中華蘇維埃共和國憲法大綱”中的宗教政策[Religious policy in the “Constitutional Programme of the Chinese Soviet Republic”]. Beijing dangshi 2003/2: 23-26. Williams, C. Peter. 2008. "The Church Missionary Society and the Indigenous Church in the Second Half of the Nineteenth Century: The Defense and Destruction of the Venn Ideals". In 
Converting Colonialism. Visions and Realities in Mission History, 1706-1904, ed. Dana L. Robert. Grand Rapids, MI: Eerdmans, 86-111.

Williams, C. Peter. 1990. The Ideal of the Self-Governing Church. A Study in Victorian Missionary Strategy. Leiden: Brill.

Wolf, Arthur P. 1978. Gods, Ghosts, and Ancestors. In Studies in Chinese Society, ed. Arthur P. Wolf. Stanford, CA: Stanford University Press, 131-182.

Xu, Yihua. 2004. "Patriotic" Protestants: The Making of an Official Church. In God and Caesar in China. Policy Implications of Church-State Tensions, ed. Jason Kindopp, Carol Lee Hamrin. Washington, DC: Brookings Institution Press, 107-121.

Yang, C. K. 1961. Religion in Chinese Society. A Study of Contemporary Social Functions of Religion and Some of their Historical Factors. Berkeley, CA and Los Angeles: University of California Press.

Yang Fenggang. 2006. The Red, Black, and Gray Markets of Religion in China”. Sociological Quarterly 47: 93-122.

Yang, Fenggang, Joseph B. Tamney (eds.). 2005. State, Market, and Religions in Chinese Societies. Leiden/Boston, MA: Brill.

Yates, M. T. 1878. Ancestor Worship. A Revised Edition of an Essay Read before the Missionary Conference Held at Shanghai May 10-24, 1877. Shanghai: American Presbyterian Mission Press.

Yip, Ka-Che. 1995. Health and National Reconstruction in Nationalist China. The Development of Modern Health Services, 1928-1937. Ann Arbor, MI: Association for Asian Studies.

Zetzsche, Jost. 1999. The Bible in China. The History of the Union Version or the Culmination of Protestant Missionary Bible Translation in China. Nettetal: Steyler Verlag.

Zha Shijie. 査時傑 1993. Minguo Jidujiao shi lunwenji 民國基督教史論文集 [Collected Essays on Christianity in Republican China]. Taipei: Yuzhouguang.

Zhang Zuji 張祖基. 1980. Zhonghua jiu lisu 中華舊禮俗 [The Old Customs of China]. 4 vols. Tokyo: Riben Chongzheng Zonghui/Shijie Keshu Di-Wu Ci Kenqin Dahui Shoubei Yuanqin Weiyuanhui (Original manuscript 1928-1934).

Zhao Shuhao 趙樹好. 2001. Jiao'an yu wan Qing shehui 教案與晚清社會 [Missionary Cases and Late Qing Society]. Beijing: Zhongguo Wenlian Chubanshe. 